\title{
Article
}

\section{Antimicrobial Activity of Cellulose Based Materials}

\author{
Nicoleta Sorina Nemeş ${ }^{1}\left(\mathbb{D}\right.$, Cristina Ardean ${ }^{2}$, Corneliu Mircea Davidescu ${ }^{1} * \mathbb{1}$, Adina Negrea ${ }^{2} \oplus$, Mihaela Ciopec ${ }^{2}$, \\ Narcis Duţeanu ${ }^{2, *} \mathbb{C}$, Petru Negrea ${ }^{2}$, Cristina Paul ${ }^{2}$ (D) Daniel Duda-Seiman ${ }^{3}$ and Delia Muntean ${ }^{4}(\mathbb{D}$
}

1 Renewable Energy Research Institute-ICER, Politehnica University of Timisoara, 138 Gavril Musicescu Street, 300501 Timisoara, Romania; nicoleta.nemes@upt.ro

2 Faculty of Industrial Chemistry and Environmental Engineering, Politehnica University of Timişoara, 2 Piaţa Victoriei, 300006 Timisoara, Romania; cristina.ardean@student.upt.ro (C.A.); adina.negrea@upt.ro (A.N.); mihaela.ciopec@upt.ro (M.C.); petru.negrea@upt.ro (P.N.); cristina.paul@upt.ro (C.P.)

3 Department of Cardiology, "Victor Babeş" University of Medicine and Pharmacy Timişoara, 2 Piata Eftimie Murgu, 300041 Timisoara, Romania; dannymduda@gmail.com

4 Multidisciplinary Research Center on Antimicrobial Resistance, Department of Microbiology, "Victor Babeş" University of Medicine and Pharmacy, 2 Eftimie Murgu Square, 300041 Timisoara, Romania; muntean.delia@umft.ro

* Correspondence: corneliu.davidescu@upt.ro (C.M.D.); narcis.duteanu@upt.ro (N.D.)

Citation: Nemeş, N.S.; Ardean, C.; Davidescu, C.M.; Negrea, A.; Ciopec, M.; Duţeanu, N.; Negrea, P.; Paul, C.; Duda-Seiman, D.; Muntean, D. Antimicrobial Activity of Cellulose Based Materials. Polymers 2022, 14 , 735. https://doi.org/10.3390/ polym 14040735

Academic Editor: Luis Alves

Received: 20 January 2022

Accepted: 13 February 2022

Published: 14 February 2022

Publisher's Note: MDPI stays neutral with regard to jurisdictional claims in published maps and institutional affiliations.

Copyright: (C) 2022 by the authors. Licensee MDPI, Basel, Switzerland. This article is an open access article distributed under the terms and conditions of the Creative Commons Attribution (CC BY) license (https:// creativecommons.org/licenses/by/ $4.0 /)$.

\begin{abstract}
Biomaterials available for a wide range of applications are generally polysaccharides. They may have inherent antimicrobial activity in the case of chitosan. However, in order to have specific functionalities, bioactive compounds must be immobilized or incorporated into the polymer matrix, as in the case of cellulose. We studied materials obtained by functionalizing cellulose with quaternary ammonium salts: dodecyl-trimethyl-ammonium bromide (DDTMABr), tetradecyl-trimethylammonium bromide (TDTMABr), hexadecyl-trimethyl ammonium chloride (HDTMACl), some phosphonium salts: dodecyl-triphenyl phosphonium bromide (DDTPPBr) and tri n-butyl-hexadecyl phosphonium bromide (HDTBPBr) and extractants containing sulphur: 2-mercaptobenzothiazole (MBT) and thiourea (THIO). Cel-TDTMABr material, whose alkyl substituent chain conformation was shortest, showed the best antimicrobial activity for which, even at the lowest functionalization ratio, 1:0.012 (w:w), the microbial inhibition rate is 100\% for Staphylococcus aureus, Escherichia coli, and Candida albicans. Among the materials obtained by phosphonium salt functionalization, CelDDTPPBr showed a significant bactericidal effect compared to Cel-HDTBPBr. For instance, to the same functionalization ratio $=1: 0.1$, the inhibition microbial growth rate is maximum in the case of Cel-DDTPPBr for Staphylococcus aureus, Escherichia coli, and Candida albicans. At the same time, for the Cel-HDTBPBr material, the total bactericidal effect is not reached even at the functionalization ratio 1:0.5. This behavior is based on the hydrophobicity difference between the two extractants, DDTPPBr and HDTBPBr. Cel-MBT material has a maximum antimicrobial effect upon Staphylococcus aureus, Escherichia coli, and Candida albicans at functionalized ratio = 1:0.5. Cel-THIO material showed a bacteriostatic and fungistatic effect, the inhibition of microbial growth being a maximum of $76 \%$ for Staphylococcus aureus at the functionalized ratio $=1: 0.5$. From this perspective, biomaterials obtained by SIR impregnation of cellulose can be considered a benefit to be used to obtain biomass-derived materials having superior antimicrobial properties versus the non-functional support.
\end{abstract}

Keywords: cellulose; antimicrobial activities; functionalized materials; cellulose derivatives

\section{Introduction}

Cellulose is one of the major components of plant cell walls. Cellulose is mainly obtained from natural resources such as plant materials: grass (bamboo), straw (wheat, rice, barley), leaves (pineapple, palm), fibers (flax, jute, hemp, sugar cane, sisal) [1,2], wood and wood residues such as wood chips or branches [1,3-6], marine animals [6,7], fungi, algae and bacteria $[6,8-12]$. 
Regardless of the source $[13,14]$, cellulose can be characterized as a linear homopolysaccharide with high molecular weight, consisting of monomer units arranged alternately with an angle of $180^{\circ} \mathrm{C}$ between them, linked by $\beta-1,4$ bonds $[15,16]$. The repeating segment is a glucose dimer known as cellobiose $[6,14,17]$. Each monomer unit, identified as an anhydrous-glucose unit, has three hydroxyl groups, giving cellulose the most important properties and determining its microfibrillated structure $[2,9,14]$ and the hierarchical organization in crystalline and amorphous regions and the extremely cohesive structure of the molecule $[7,18]$.

Each cellulose chain has a directional asymmetry of its molecular axis with respect to the ends. One end has reduced chemical functionality due to the hemiacetal unit being a COC-shaped etheric bridge. The other end has "pendant" type hydroxyl groups with no reduction properties [14]. However, hydroxyl groups play a major role in forming covalent bonds with various reactants [19], which increase the chemical activity of cellulose and thus the antibacterial effect.

Due to the biocompatibility and biodegradability of cellulose [20], but also through the production of a wide range of cellulose derivatives [21], this biopolymer is used in various technological fields: in the food industry, it is used as a gelling or stabilizing agent [20,22], while in cosmetics it is used as a scrub or water retention agent $[16,23,24]$, emulsifier [22,25], stabilizer of suspensions in paste and cream [24]. Other applications are in the paper industry [23], textile industry [16,23], and leather [26] or as combustible [27]. Various materials made from bacterial cellulose and polymeric compounds were tested to obtain artificial bones, cartilage, or other medical devices [23,28]. Of all the known types, the most studied form of cellulose for obtaining materials with antibacterial properties was cellulose with Ag nanoparticles, considering the antibacterial potential of Ag nanoparticles [11,29-31].

Microcrystalline cellulose (like the cellulose used in this study, Avicel PH 101) is a partially depolymerized pure cellulose synthesized from the $\alpha$-cellulose precursor (type $I \beta)$. This type of cellulose is considered a remarkable excipient. It remains the most widely used and the strongest dry binder, disintegrating tablet coating, absorbent, lubricant, and non-stick material [32]. Cellulose has good water purifying effects [16,33] because it has many free - $\mathrm{OH}$ groups on the chain, allowing the efficient removal of metal ions and organic matter from water [33] having an excellent chelating effect. However, due to its low water solubility and relatively low chemical reactivity, the use of unmodified cellulose as a flocculant is limited [34]. Modified, water-soluble (hydrophilic) cellulose plays a very important role as a potential substitute for oil-based flocculants [35]. Some cellulose derivatives have already been successfully tested to remove suspended solids. There is also a growing interest in developing low-cost biomass (cellulosic) absorbents for the treatment of colour-contaminated wastewater (agricultural, industrial, municipal waste). Thus, anionic sodium carboxymethylcellulose, prepared from palm agricultural waste, has been tested as an environmentally friendly flocculant coupled with aluminum sulfate as a coagulant to remove turbidity in drinking water treatment $[34,36]$.

As was said, natively, cellulose has a relatively low reactivity [5]. Therefore, introducing new functional groups on the cellulose structure can increase the polarity and hydrophilicity of its surface [23], which can increase the adsorption of polar compounds and the selectivity of cellulose for the targeted pollutant. However, the chemical modification of this natural polymer is slightly difficult due to its relatively low reactivity. This is also influenced by the many hydrogen bonds that decrease the potential solubility in most common solvents [23]. Typically, the modification of cellulose fibers is achieved by heterogeneous synthesis [23,37], which can lead to some unexpected by-products [37] or the decomposition of cellulose. Although obtaining materials with antibacterial properties based on cellulose by simply mixing with antibacterial agents could be a way to induce antibacterial activity to the biocellulose, antibacterial agents being leached during use and thus bioactivity will decrease. That is why it is preferable to obtain cellulose derivatives by grafting chains with antibacterial activity on the cellulose skeleton, as we will show in this paper. Quaternary ammonium salts or polymers containing quaternary ammonium 
groups are well known for their increased antibacterial activity [5,21,38]. On the other hand, by impregnating cellulose with various extractants containing active groups (SIR Method) [39-42], the use of harsh reaction conditions is avoided, which is in accordance with the principles of green chemistry.

\section{Materials and Methods}

\subsection{Obtaining and Characterizing Materials}

The cellulose used to obtain the materials used in the present study (powder, Avicel PH-101, Sigma-Aldrich, Merck, KGaA, Darmstadt, Germany) was used as a support, and dodecyl-trimethyl-ammonium bromide (DDTMABr-Acros Organics, Waltham, MA, USA), tetradecyl-trimethyl-ammonium bromide (TDTMABr-ThermoFisher, Waltham, MA, USA, purity 98\%), hexadecyl-trimethyl ammonium chloride (HDTMACl-ThermoFisher, Germany, purity 98\%), dodecyl-triphenyl phosphonium bromide (DDTPPBr-Thermo Fisher, Germany purity 98\%), tri n-butyl-hexadecyl phosphonium bromide (HDTBPBrThermoFisher, Germany, purity 98\%), 2-mercaptobenzothiazole (MBT-Janssen Chemistry, Bucharest, Romania), thiourea (THIO_Fluka AG, Charlotte, NC, USA). The method used to obtain the materials was the dry method SIR (Solvent Impregnated Resin), by which the support is functionalized by impregnation [41]. The support and the extractant (dissolved in distilled water) are in contact for $24 \mathrm{~h}$ at $323 \mathrm{~K}$. Then, the obtained sample is filtered, and the material obtained is dried in an oven (POLENKO SLW53, Poland). Materials were obtained in which the support:extractant $(\mathrm{w} / \mathrm{w})$ ratio of is different, namely: 1:0.012; 1:0.025; 1:0.050; $1: 0.075 ; 1: 0.1 ; 1: 0.2 ; 1: 0.3 ; 1: 0.4 ; 1: 0.5$. The obtained material was characterized by scanning electron microscopy, SEM, and X-ray energy dispersion (EDX), using the X-ray energy dispersion spectrometer and the FEI Quanta FEG 250 instrument (FEI, Hillsboro, OR, USA).

\subsection{Bacterial Culture Preparation}

(a) Microbial cultures preparation, in order to establish the optimal cellulose: extractant ratio

Bacterial cultures were obtained by inoculating a non-selective solid nutrient medium into which the test material was incorporated, then poured into Petri dishes, with a bacterial suspension of approx. $1 \times 10^{8} \mathrm{UFC} / \mathrm{mL}$ (0,5 Mc Farland). Completely dehydrated culture medium was used for all seedings, Plate Count Agar-produced by Merck (Peptone from Casein $5.0 \mathrm{~g} / \mathrm{L}$; Yeast Extract $2.5 \mathrm{~g} / \mathrm{L}$; D (+)-Glucose $1.0 \mathrm{~g} / \mathrm{L}$; Agar $14.0 \mathrm{~g} / \mathrm{L})$.

In each set of experiments, a Petri dish containing the control sample (M0-control sample) was seeded, consisting of culture medium and $1 \mathrm{~mL}$ of bacterial inoculum, and a Petri dish containing culture medium, bacterial inoculum, and non-functionalized support material, in solid-state (M1-cellulose (Cel)).

Each functionalized material (containing both supporting and extracting material) to be tested was analysed in all functionalization ratios: 1:0.012; 1:0.025; 1:0.050; 1:0.075; 1:0.1; $1: 0.2 ; 1: 0.3 ; 1: 0.4 ; 1: 0.5$. An amount of non-functionalized or functionalized solid material of about $0.2 \mathrm{~g}$ was used in each Petri dish, which was distributed as evenly as possible in the culture medium and $1 \mathrm{~mL}$ of bacterial inoculum (approx. $1 \times 10^{8} \mathrm{UFC} / \mathrm{mL}$ ), in an amount of culture medium of about $15 \mathrm{~mL}$.

All inoculations were performed with 3 repetitions. The plates were incubated for $48 \mathrm{~h}$ at $310 \mathrm{~K}$. Subsequently, the colonies developed on the surface of the Petri dishes were counted using an automatic colony counter produced by YUL (Flash\&Go, YUL Instruments SA, Barcelona, Spain).

(b) Microbial cultures preparation for further tests of antimicrobial effect of the synthesized materials on the reference strains

In order to test the antimicrobial effect of the synthesized materials on the reference microbial strains, both the optimal support:extractant ratios determined in the first stage and other support:extractant ratios were considered so that the efficiency of the function- 
alization ratio can be monitored. In order to establish the efficacy of the functionalized material, microbiological control tests were performed on $1 \times 10^{5} \mathrm{CFU} / \mathrm{mL}$ of reference microbial strains (Thermo Scientific, Waltham, MA, USA). To highlight these effects on Gram-negative bacteria, strains of Escherichia coli ATCC 25922 and Pseudomonas aeruginosa ATCC 27853 were studied, while the effect of the materials on Gram-positive bacteria was studied on the strain of Staphylococcus aureus ATCC 25923. Candida albicans strain ATCC 10231 was used to observe the antifungal activity. All determinations were performed with 3 repetitions. The plates were incubated for $48 \mathrm{~h}$ at $310 \mathrm{~K}$. The number of colonies developed on the surface of the work plates was determined using the automatic colony counter from YUL instruments (YUL Instruments SA, Barcelona, Spain). The efficiency of the functionalized material on the reference strains was expressed as the rate of inhibition of microbial growth [43-45], calculated as the ratio between the number of colony-forming units on functionalized and non-functionalized material, expressed as a percentage ratio, according to the equation:

$$
\text { inhibition rate }=\frac{\left[U F C_{\text {control }}-U F C_{\text {test }}\right]}{U F C_{\text {control }}} \times 100
$$

$U F C_{\text {control }}=$ number of colonies on the control plate

$U F C_{\text {test }}=$ the number of colonies on the test plate

Using this method, the optimal support:extractant ratio was established, representing the optimum ratio at which no microbial growth was observed or the case when the rate of inhibition of microbial growth was the highest.

Total bactericidal effect was considered where the rate of inhibition of bacterial growth was $100 \%$.

\section{Results and Discussion}

\subsection{Characterization of Materials Obtained by Cellulose Functionalizing}

Obtained materials were characterized by scanning electron microscopy, SEM, Xray energy dispersion, EDX and infrared spectroscopy with Fourier transform, FT-IR to highlight the presence of pending groups $\mathrm{N}, \mathrm{P}$, and $\mathrm{S}$ of the extractant (DDTMABr, TDTMABr, HDTMACl, DDTPPBr, HDTBPBr, MBT and THIO) on the support surface (Cel).

\section{a. Scanning electron microscopy, SEM}

To highlight the morphology of the support surface (cellulose), as well as of the materials obtained by impregnation by functionalization with the extractants DDTMABr, TDTMABr, HDTMACl, DDTPPBr, HDTBPBr, MBT, and THIO, the probes were analyzed by scanning electron microscopy operated at $10 \mathrm{kV}$ and a magnification of $2000 \times$ (obtained micrograph being presented in Figure 1). The assays were performed in a low vacuum to prevent the sample's destruction.

It can be seen from Figure 1 that for all obtained materials, cellulose fibers are more agglomerated due to the functionalization. It was observed that the obtained materials have more slender fibers. However, the major structural difference between control and extractants-treated cellulose fibers was not clearly observed [46].

This morphological change is attributed to the swelling and partial disintegration of the cellulosic fibers during the surface modification process, followed by the insertion of amine moieties that cover the surface of the fibers $[47,48]$. Nevertheless, analogous micro-sized fibers with a rough and rod-shaped surface microstructure are revealed for samples based on microcrystalline cellulose, demonstrating the homogenous surface functionalization without much variation of surface morphology. 


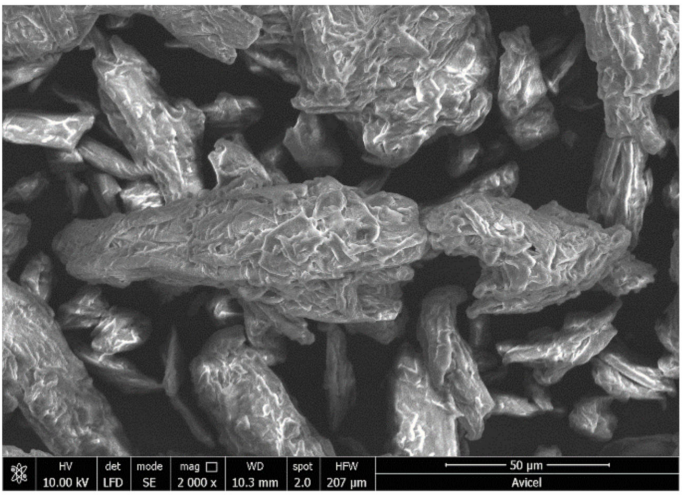

(a)

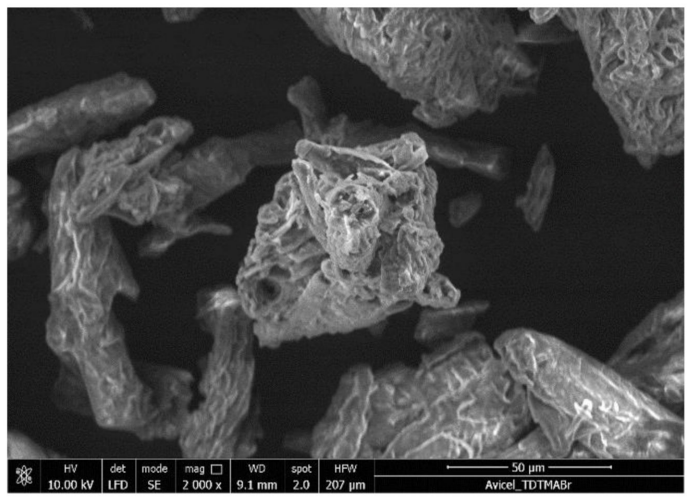

(c)

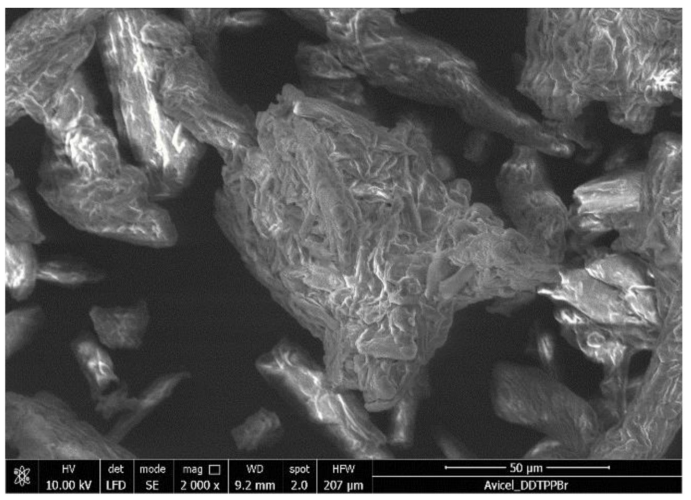

(e)

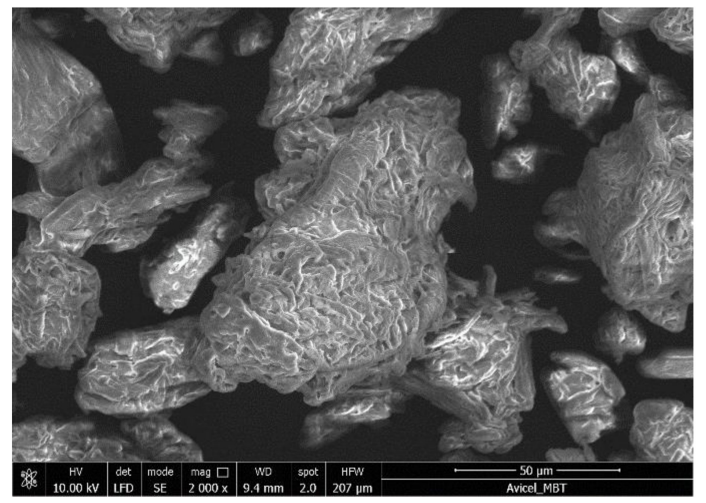

(g)

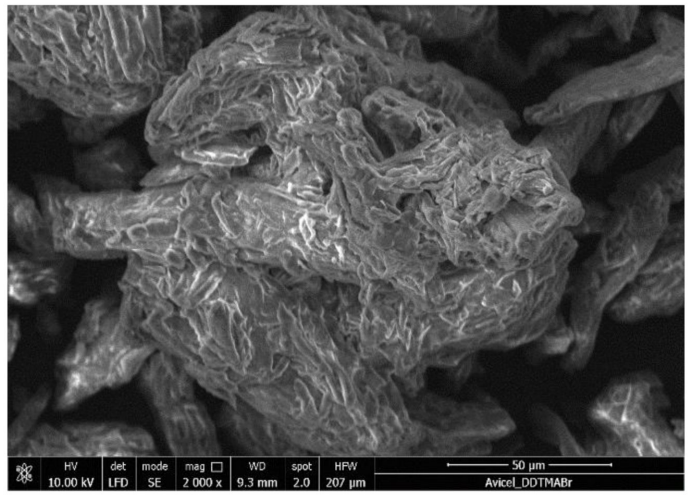

(b)

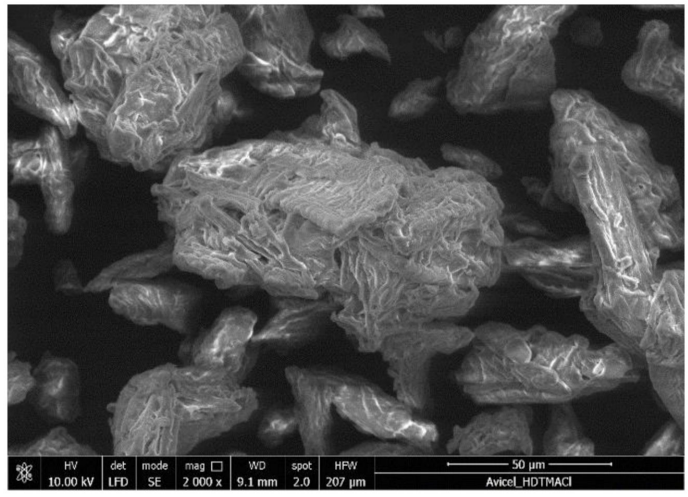

(d)

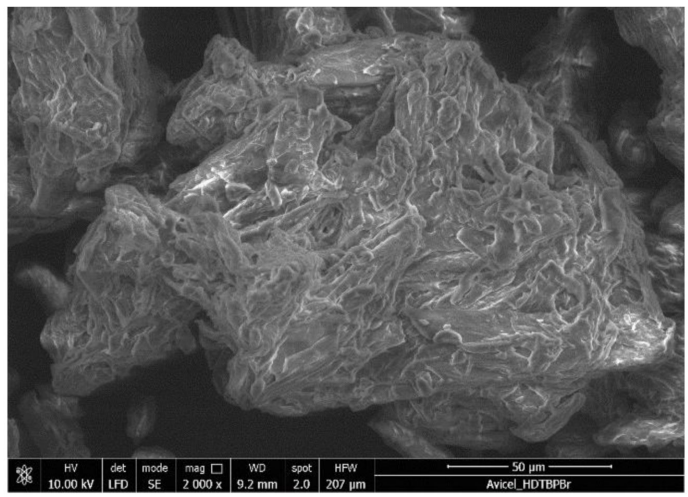

(f)

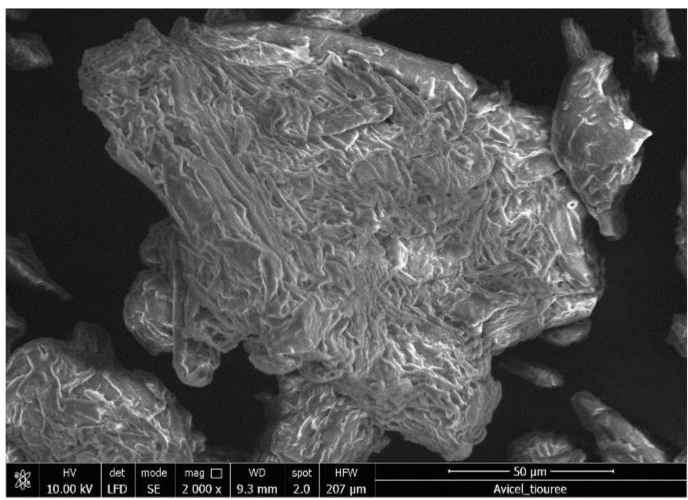

(h)

Figure 1. Scanning electron microscopy, SEM. (a). Cellulose (Cel); (b). Cel-DDTMABr; (c). CelTDTMABr; (d). Cel-HDTMACl; (e). Cel-DDTPPBr; (f). Cel-HDTBPBr; (g). Cel-MBT; (h). Cel-THIO. 


\section{b. X-ray energy dispersion, EDX}

The EDX spectra for support, Cel, and the obtained materials are presented in Figure 2.

Figure 2a shows the peaks specific to the composition of cellulose, namely $\mathrm{C}$ and $\mathrm{O}$. Figure $2 b-h$ shows the specific EDX spectra representing the specific peaks of the elements present in the composition of cellulose and the extractants. Thus, in Figure 2b,c there are drawn the specific peaks of the DDTMABr and TDTMABr extractants, associated with the presence of $\mathrm{Br}$ and $\mathrm{N}$ atoms, and in Figure 2d, in addition to the specific peak of N, there is also the specific peak in case of $\mathrm{Cl}$. Figure $2 \mathrm{e}, \mathrm{f}$ show specific $\mathrm{P}$ and $\mathrm{Br}$ peaks, elements that are present in the DDTPPBr and $\mathrm{HDTBPBr}$ extractants. In Figure $2 \mathrm{~g}, \mathrm{~h}$. specific $\mathrm{S}$ and N peaks appear, elements that are present in the MBT and THIO extractants. These observations reveal a successful functionalization of the natural polymer with thiourea extractant [49].

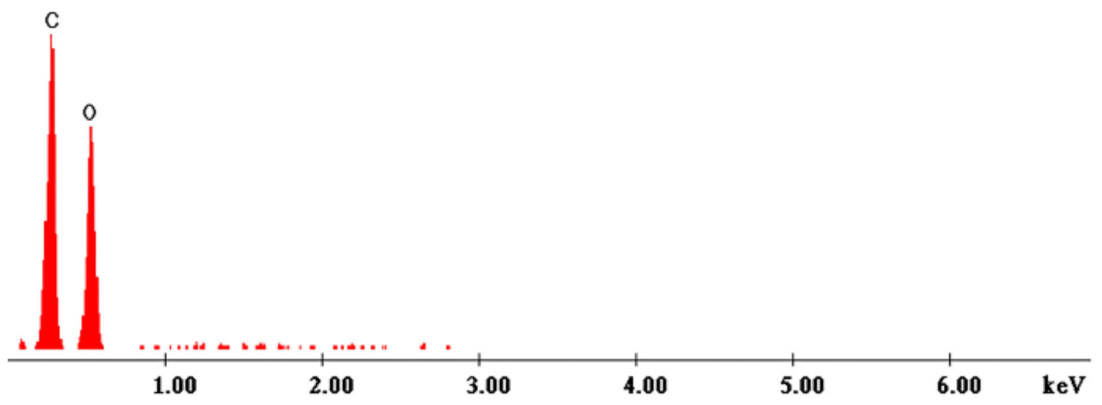

(a)

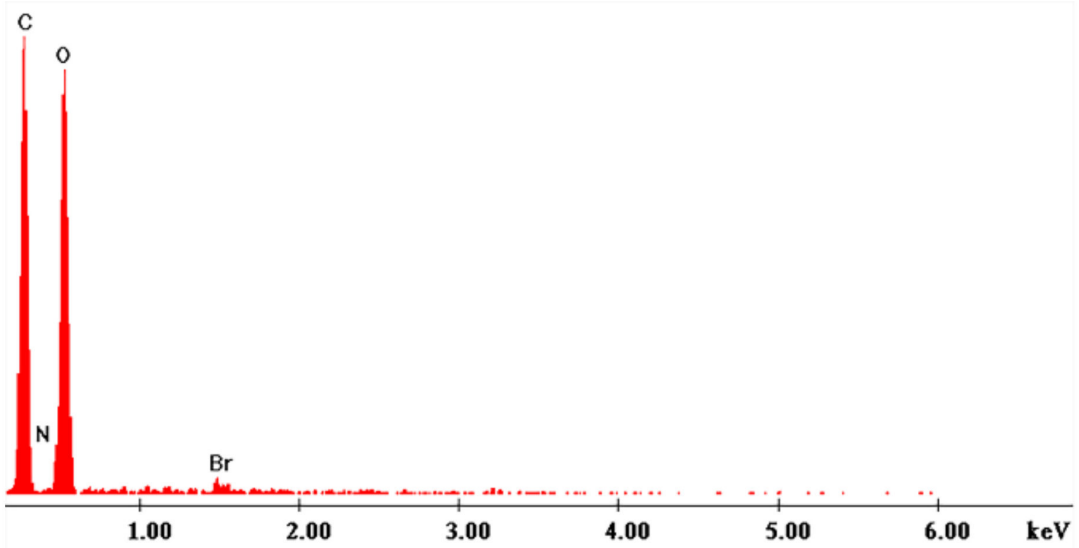

(b)

Figure 2. Cont. 


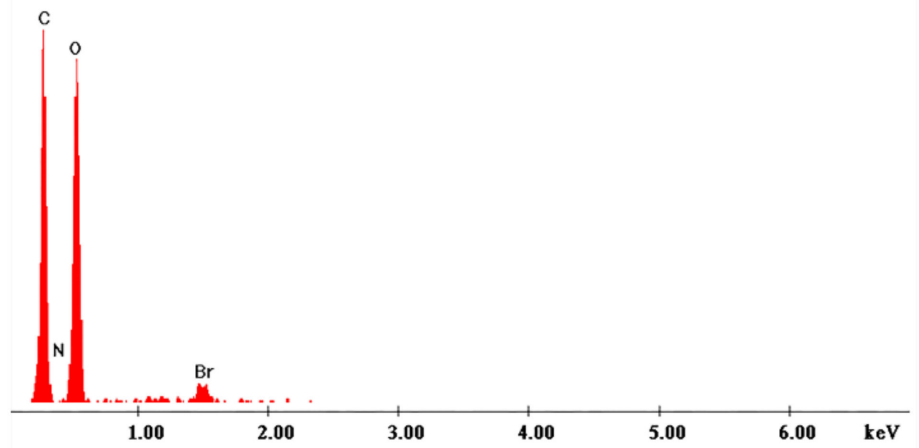

(c)

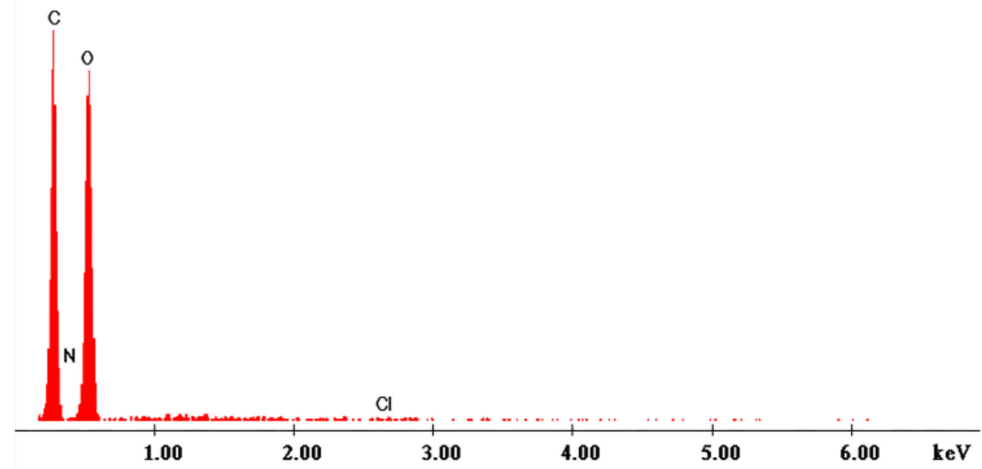

(d)

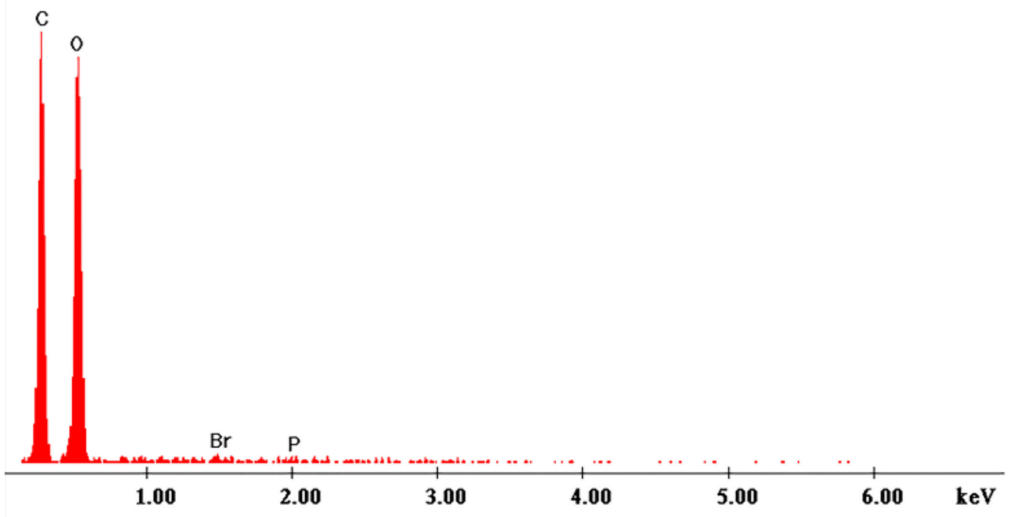

(e)

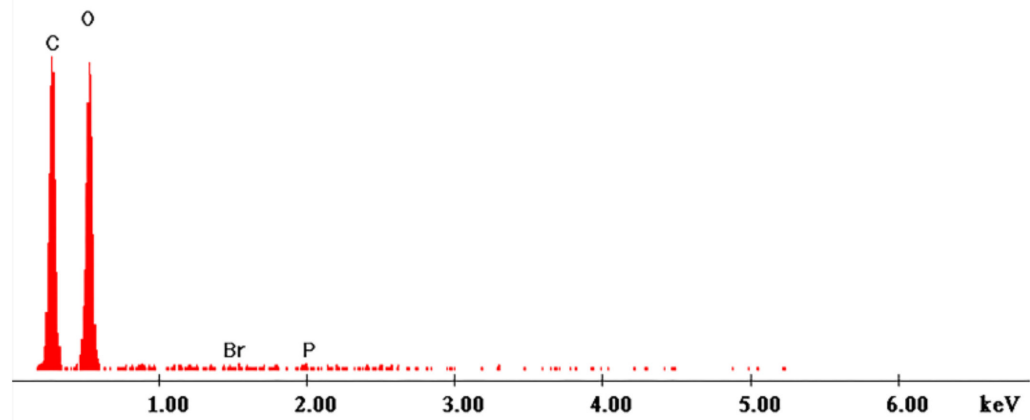

(f)

Figure 2. Cont. 


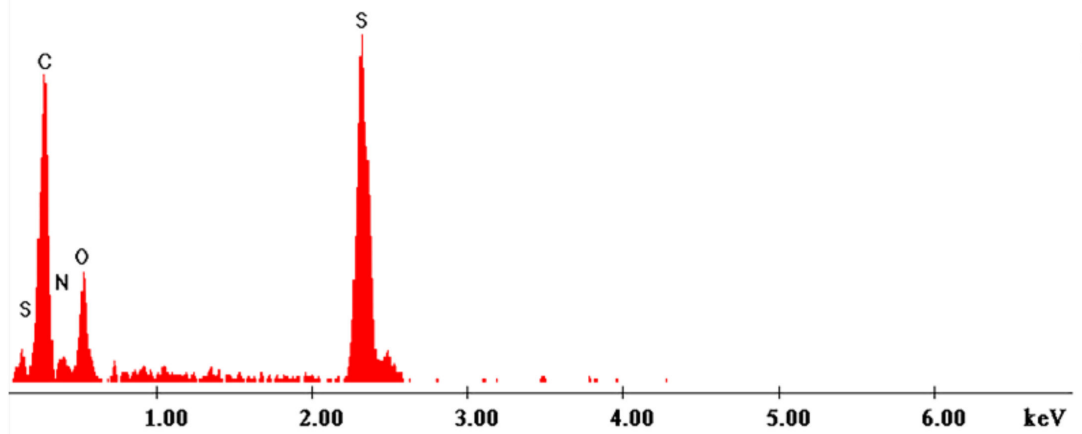

(g)

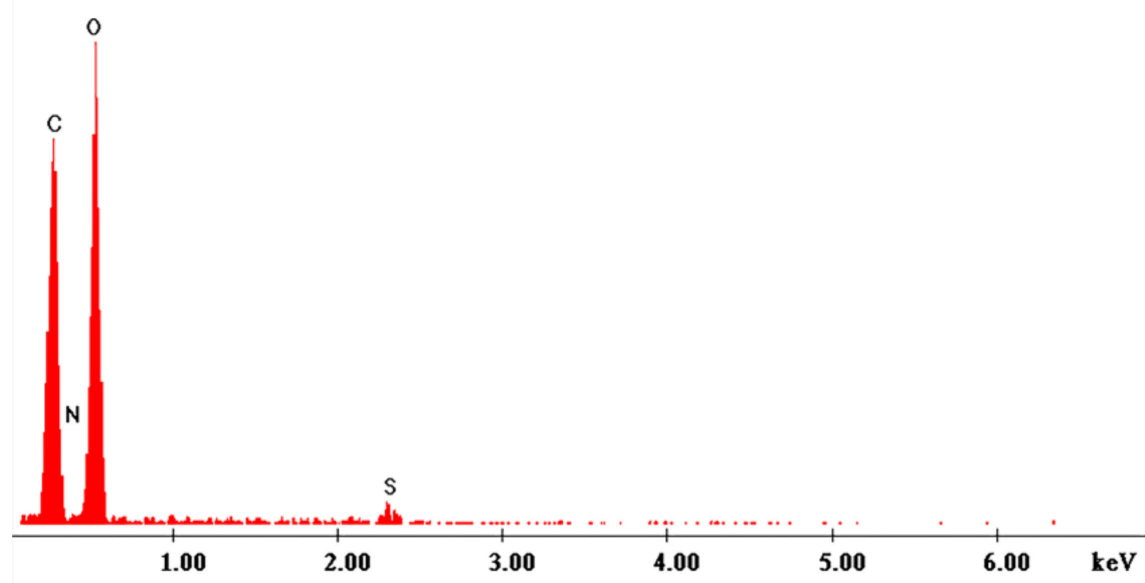

(h)

Figure 2. X-ray energy dispersion spectra recorded for pure cellulose and for prepared materials. (a). Cellulose (Cel); (b). Cel-DDTMABr; (c). Cel-TDTMABr; (d). Cel-HDTMACl; (e). Cel-DDTPPBr; (f). Cel-HDTBPBr; (g). Cel-MBT; (h). Cel-THIO.

c. Infrared spectroscopy with Fourier transform, FT-IR

In order to identify those functional groups specific to the extractants used for cellulose functionalization, cellulose and newly obtained materials FT-IR spectra were performed. These spectra are shown in Figure 3.

Based on the presented data, it can be stated that cellulose was successfully functionalized with the seven studied extractants. Small displacements of hydroxylic groups stretching vibrations observed in FT-IR spectra recorded for functionalized cellulose were associated with the formation of hydrogen bonds (physical intermolecular bonds) between used extractants and cellulosic free hydroxyl groups. This observation was in concordance with the low reactivity of cellulose in used working conditions, when only the cellulose swelling is taking place. 


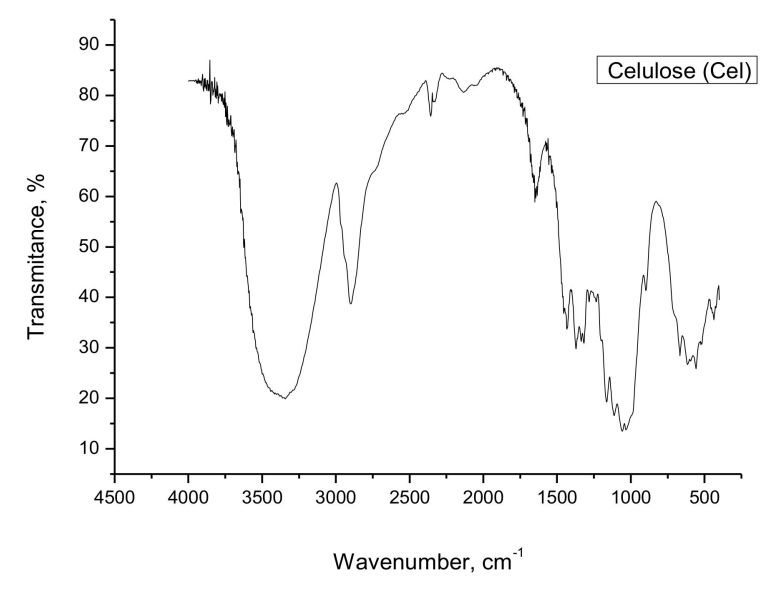

(a)

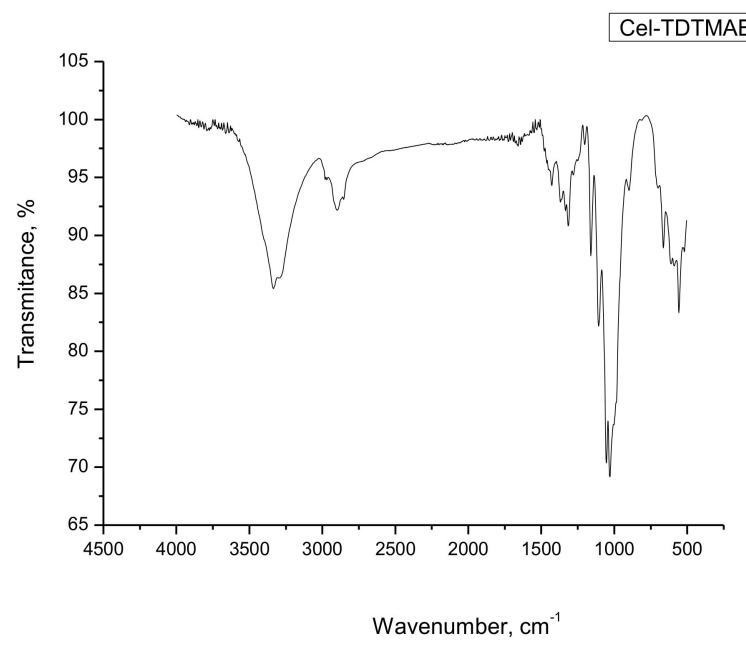

(c)

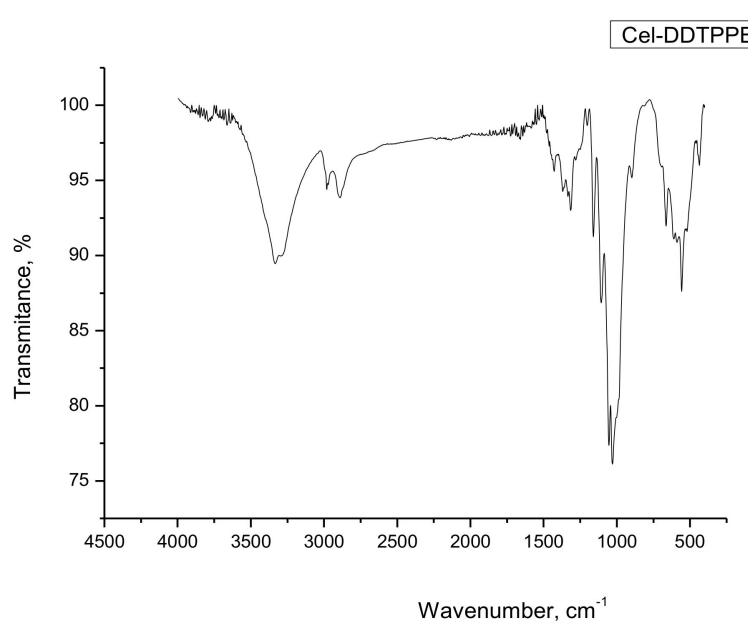

(e)

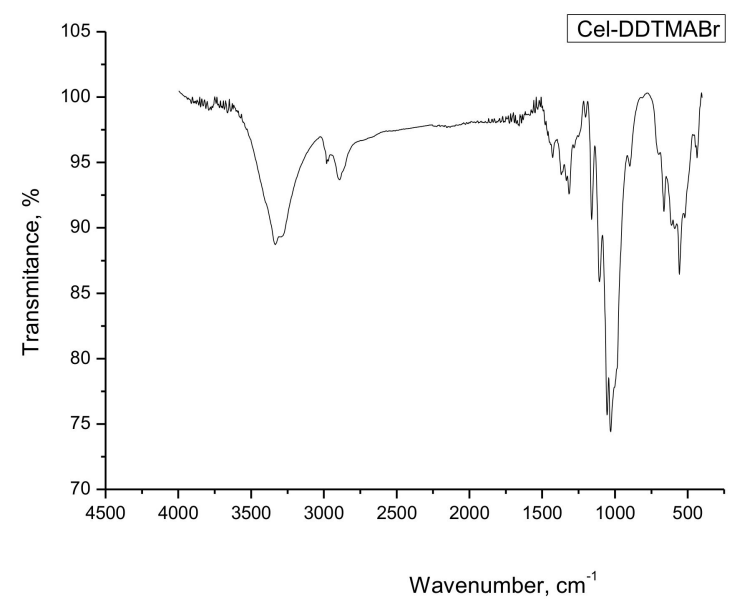

(b)

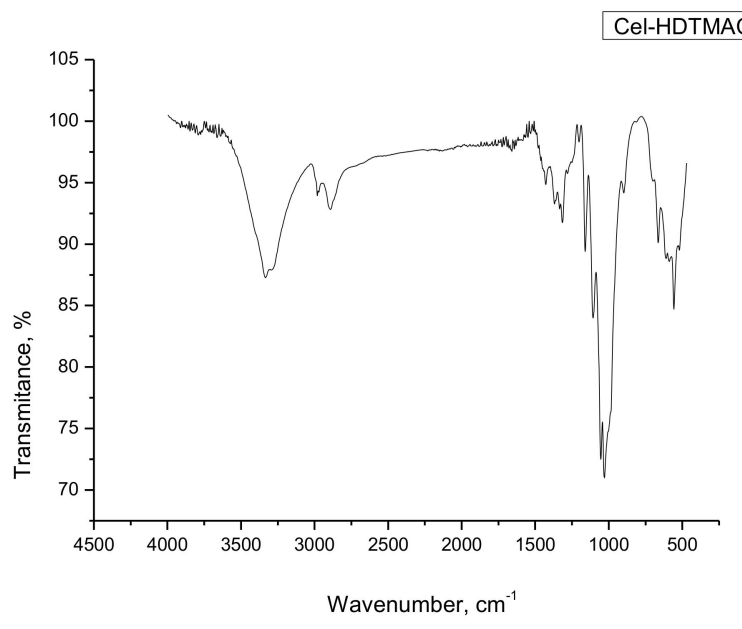

(d)

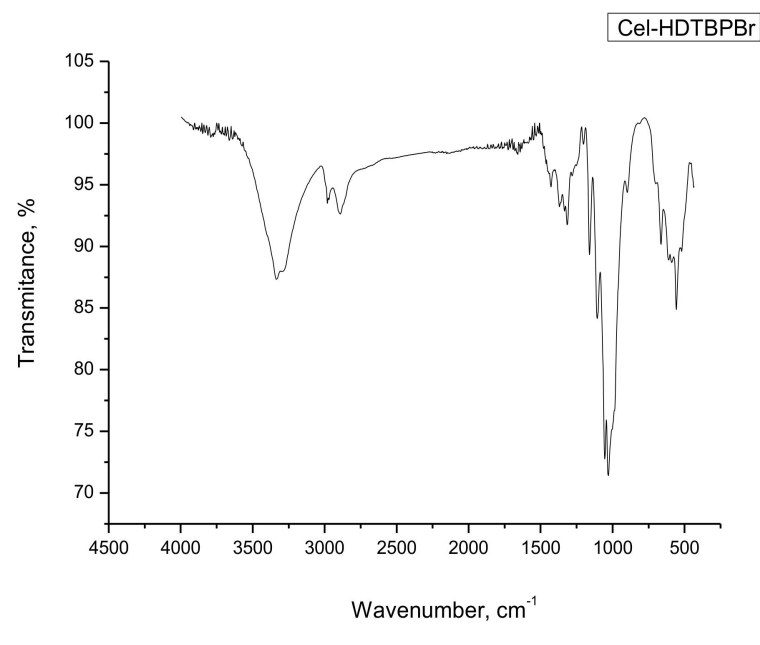

(f)

Figure 3. Cont. 


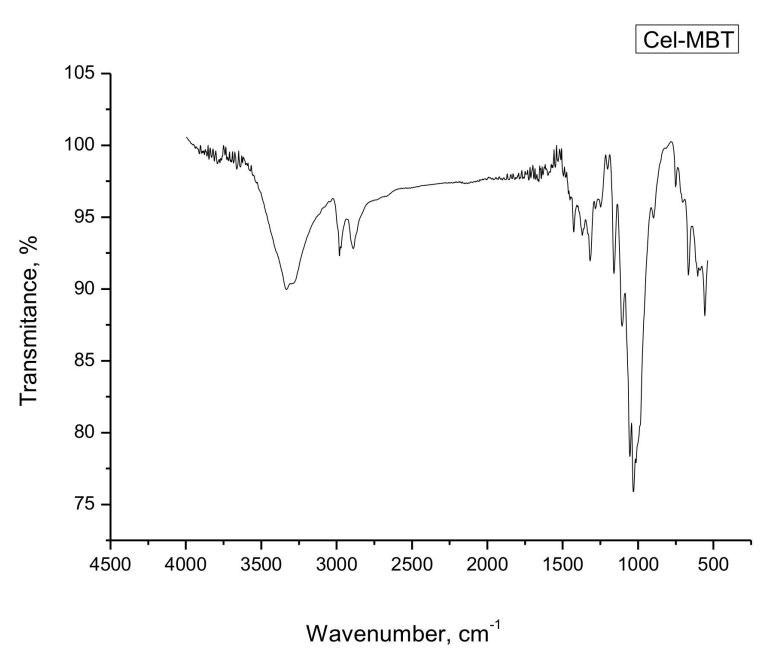

(g)

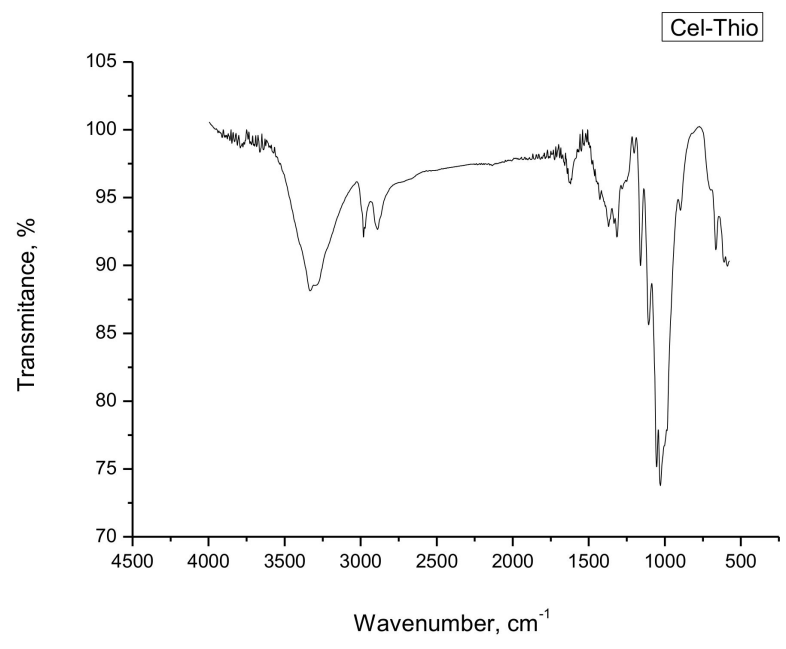

(h)

Figure 3. FT-IR spectra recorded for cellulose and for produced materials. (a) Cellulose (Cel); (b) CelDDTMABr; (c) Cel-TDTMABr; (d) Cel-HDTMACl; (e) Cel-DDTPPBr; (f) Cel-HDTBPBr; (g) Cel-MBT; (h) Cel-THIO.

There are small differences due to the presence of active groups in the extractants. Table 1 shows the bands specific to the cellulose and extractant groups.

Table 1. FT-IR specific bands in cellulose and extractants $[49,50]$.

\begin{tabular}{|c|c|c|}
\hline Group & FT-IR Bands $\left(\mathrm{cm}^{-1}\right)$ & Observations \\
\hline \multicolumn{3}{|c|}{ Cellulose (Cel) } \\
\hline $\begin{array}{l}\mathrm{O}-\mathrm{H} \\
\mathrm{C}-\mathrm{H}\end{array}$ & $\begin{array}{l}3660 \\
2893\end{array}$ & $\begin{array}{c}\text { Large band } \\
\text { Small plateau; stretching vibrations } \\
\text { in polysaccharides }\end{array}$ \\
\hline $\begin{array}{c}\mathrm{CH}_{2} \\
\mathrm{C}-\mathrm{O} \\
\mathrm{O}-\mathrm{C}-\mathrm{O}\end{array}$ & $\begin{array}{c}1428 ; 1367 \\
1334 ; 1158 \\
1104 ; 1027 \\
897\end{array}$ & $\begin{array}{l}\text { Vibrations specific to the crystalline structure } \\
\text { of cellulose }\end{array}$ \\
\hline $\mathrm{OH}_{2}$ & $\begin{array}{c}1600-900 \\
1633\end{array}$ & $\begin{array}{l}\text { Amorphous region in cellulose } \\
\text { Water molecules vibrations }\end{array}$ \\
\hline \multicolumn{3}{|c|}{ Cel-DDTMABr } \\
\hline$>\mathrm{N}-\mathrm{CH}_{2}$ & $2700-2800$ & specific link $\mathrm{e}^{-}$nonparticipants from $\mathrm{N}$ \\
\hline \multicolumn{3}{|c|}{ Cel-TDTMABr } \\
\hline$>\mathrm{N}-\mathrm{CH}_{2}$ & $2700-2800$ & specific link $\mathrm{e}^{-}$nonparticipants from $\mathrm{N}$ \\
\hline \multicolumn{3}{|c|}{ Cel-HDTMACl } \\
\hline$>\mathrm{N}-\mathrm{CH}_{2}$ & $2700-2800$ & specific link $\mathrm{e}^{-}$nonparticipants from $\mathrm{N}$ \\
\hline \multicolumn{3}{|c|}{ Cel-DDTPPBr } \\
\hline $\begin{array}{l}\text { P-O-Aril } \\
\text { C-O (fenil) } \\
\text { O-H }\end{array}$ & $\begin{array}{l}1190-1240 \\
1200 \\
3500-3200\end{array}$ & \\
\hline \multicolumn{3}{|c|}{ Cel-HDTBPBr } \\
\hline P-O-Alchil & 1150-1180; 1080 & \\
\hline
\end{tabular}


Table 1. Cont.

\begin{tabular}{|c|c|c|}
\hline Group & FT-IR Bands $\left(\mathrm{cm}^{-1}\right)$ & Observations \\
\hline \multicolumn{3}{|c|}{ Cel-MBT } \\
\hline $\begin{array}{c}\text { S-C-S } \\
\text { C-N } \\
\text { C-H; N-H }\end{array}$ & $\begin{array}{c}568-600 \\
1030-1074 \\
1250-1320 \\
750\end{array}$ & $\begin{array}{l}\text { Aromatic ring -torsion } \\
\text { Stretching vibration }\end{array}$ \\
\hline \multicolumn{3}{|c|}{ Cel-THIO } \\
\hline$-\mathrm{NH}_{2}$ & $\begin{array}{l}3395 \\
1627\end{array}$ & $\begin{array}{c}\text { Asymmetric vibration; symmetric vibration } \\
\text { Elongation vibration }\end{array}$ \\
\hline $\begin{array}{l}\mathrm{N}-\mathrm{H} \\
\mathrm{C}=\mathrm{S}\end{array}$ & $\begin{array}{c}3179 ; 1520 \\
1425 ; 13951380 ; 12901074\end{array}$ & $\begin{array}{l}\text { Vibrations strongly influenced by } \\
\text { intramolecular effects }\end{array}$ \\
\hline
\end{tabular}

\subsection{Studies on the Antimicrobial Activity of Materials}

A. Materials obtained by functionalizing cellulose with quaternary ammonium salts

\section{A.1. Studies to determine the optimal cellulose:extractant ratio}

The bacterial activity on chitosan can be considered intrinsic due to the presence of the amino group in its basic structure. The antibacterial activity of pure cellulose (avicel) can be highlighted only in its derivatives, obtained by various chemical functionalization with antibacterial groups or by combination with natural or synthetic bioactive components or polymers and with metal nanoparticles and metal oxides [21].

In order to establish the lowest cellulose:extractant ratio, which presents a bactericidal effect on the bacterial inoculum, each material was inoculated after incorporation into the culture medium and incubated, after which the total number of colonies was determined, according to the corresponding M1 non-functionalized cellulose (Cel) control sample, respectively the $\mathrm{M} 0$ control sample corresponding to the microbial inoculum. This ratio, for which the complete absence of microbial growth was observed, was considered the optimal, minimum required ratio, producing a total bactericidal effect. However, where microbial growth was observed onto the culture media, the significant antimicrobial effect was considered the highest calculated inhibition rate.

Analyzing the data presented in Figure 4, the non-functionalized cellulose sample (M1-yellow) has an insignificant antimicrobial effect compared to the control sample (M0-red).

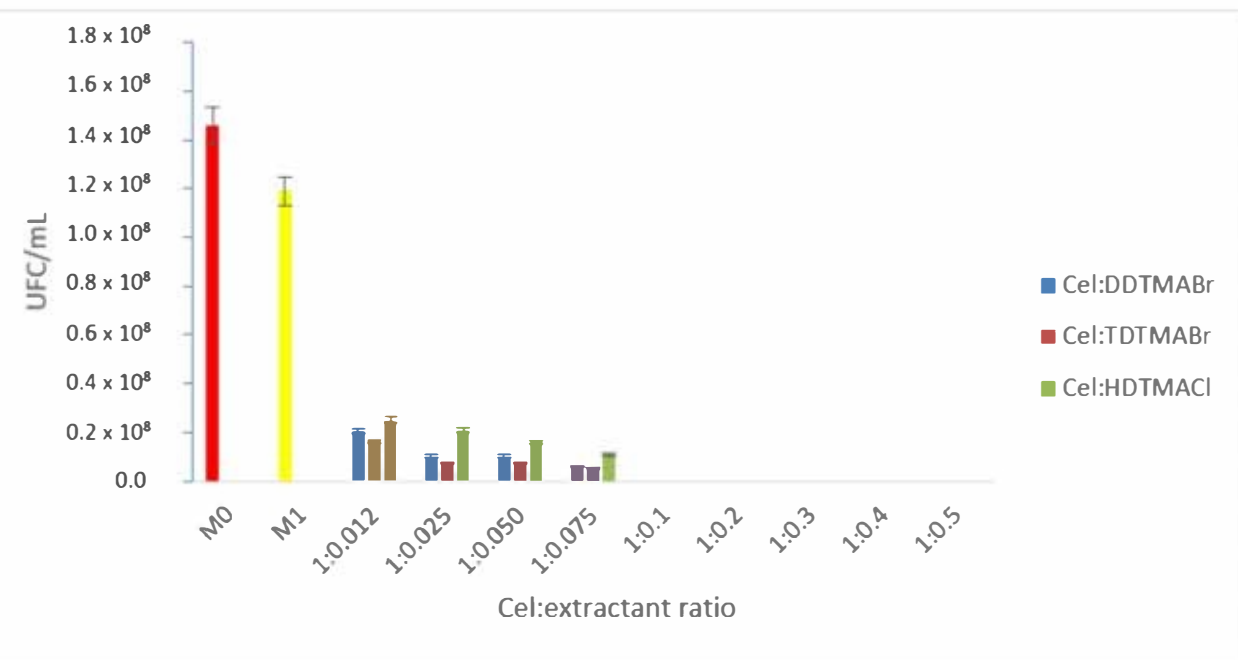

Figure 4. Comparison of the control sample (M0)—cellulose (M1)—cellulose:extractant (quaternary ammonium salts). 
Regarding the three ammonium salts used as extractants, the best antimicrobial activity was highlighted by TDTMABr, in which case the ratio Cel:TDTMABr $=1: 0.1$ expresses the fact that the inhibition rate of bacterial growth was $100 \%$. The DDTMABr extractant showed a total bactericidal effect when the ratio Cel:DDTMABr was 1:0.1 also. However, the inhibition rate of bacterial growth in the ratio of less than 1: 0.01 was lower for DDTMABr than for TDTMABr. For example, when cellulose:extractant ratio $=1: 0.075$ has been used, DDTMABr had an inhibition rate of $40 \%$, while it was $95.8 \%$ for TDTMABr, respectively. HDTMACl extractant also showed total bactericidal effect at the functional ratio Cel:HDTMACl = 1:0.01. At the same time, the bacterial growth inhibition rate calculated for the HDTMACl extractant, at all functional ratios of less than 1:0.1, was lower compared to that calculated for TDTMABr and DDTMABr, respectively.

Consequently, the optimum functional ratio to express the total bactericidal effect in the case of quaternary ammonium salt extractants was considered when the cellulose:extractant ratio was 1:0.1.

\section{A.2. Antimicrobial effect of ammonium materials on reference microbial strains}

The most accessible groups present on the cellulose surface that contribute to the formation of new materials with antibacterial properties are the hydroxyl groups at the non-reducing end of the cellulose chain. Thus, the- $\mathrm{OH}$ groups on the crystalline cellulose were grafted with quaternary ammonium compounds through an adsorption process by SIR impregnation to allow a high concentration of quaternary ammonium groups on the cellulose surface. The effects of the obtained materials on four reference strains were tested. Table 2 shows the inhibition rate of microbial growth, calculated for each tested material.

Table 2. Antimicrobial growth inhibition rate when using ammonium salts materials.

\begin{tabular}{|c|c|c|c|c|c|c|}
\hline \multirow[b]{2}{*}{ Material } & \multirow[b]{2}{*}{$\begin{array}{c}\text { Cel:Extractant } \\
\text { Ratio }\end{array}$} & \multicolumn{4}{|c|}{ Inhibition Rate (\%) } & \multirow[t]{2}{*}{ OBSERVATIONS } \\
\hline & & $\begin{array}{c}\text { Staphylococcus } \\
\text { aureus ATCC } \\
25923\end{array}$ & $\begin{array}{c}\text { Pseudomonas } \\
\text { aeruginosa ATCC } \\
27853\end{array}$ & $\begin{array}{c}\text { Escherichia coli } \\
\text { ATCC } 25922\end{array}$ & $\begin{array}{l}\text { Candida albicans } \\
\text { ATCC } 10231\end{array}$ & \\
\hline Cellulose (Cel) & - & 2.8 & 7.7 & 20 & 12.2 & $\begin{array}{c}\text { Slightly better } \\
\text { bactericidal effect } \\
\text { on Gram-negative } \\
\text { bacteria and } C \text {. } \\
\text { albicans strain }\end{array}$ \\
\hline \multirow{2}{*}{ Cel:DDTMABr } & 1:0.012 & 100.0 & 40.8 & 100.0 & 100.0 & \multirow{7}{*}{$\begin{array}{c}\text { Maximum } \\
\text { bactericidal effect } \\
\text { on Gram-positive } \\
\text { bacteria and } C \text {. } \\
\text { albicans strain }\end{array}$} \\
\hline & $1: 0.1$ & 100.0 & 52.8 & 100.0 & 100.0 & \\
\hline \multirow{2}{*}{ Cel:TDTMABr } & 1:0.012 & 100.0 & 49.9 & 100.0 & 100.0 & \\
\hline & $1: 0.1$ & 100.0 & 54.8 & 100.0 & 100.0 & \\
\hline \multirow{3}{*}{ Cel:HDTMACl } & $1: 0.012$ & 100.0 & 17.0 & 53.4 & 100.0 & \\
\hline & 1:0.05 & 100.0 & 34.3 & 58.1 & 100.0 & \\
\hline & 1:0.1 & 100.0 & 40.8 & 67.5 & 100.0 & \\
\hline
\end{tabular}

Non-functional cellulose showed a slightly better bactericidal effect on Gram-negative bacteria compared to Gram-positive ones. All cellulose derivatives based on quaternary ammonium salts used in this study (DDTMABr, TDTMABr, HDTMACl) showed very good antibacterial activity on S. aureus and C. albicans, regardless of the functionalization ratio of the support material. This effect may be due to the similar behavior of the cell wall of $S$. aureus to the fungal cell of $C$. albicans $[51,52]$. The extractant strongly adheres to the bacterial cell wall and the fungal cell membrane, damaging their structure and preventing the exchange of nutrients necessary for microbial development, which subsequently leads to cell death, meaning the accomplishment of the antimicrobial effect. Another important role in the permeability of the cell membrane is the number of fatty acids present in its structure, which subsequently correlates with the degree of penetration of the toxic element into the cell, as shown in numerous studies $[51,53]$. 
Moreover, on the E. coli strain, the bactericidal effect was maximum when using DDTMABr and TDTMABr. At the same time, for HDTMACl, the highest inhibition rate was $67.5 \%$, corresponding to the functionalization ratio $\mathrm{Cel}: \mathrm{HDTMACl}=1: 0.1$. A possible explanation would be that a particularly important role for antibacterial effect has the hydrophobic component given by the alkyl radical of the quaternary salt. On the other hand, there is the distance from the positive charge given by the quaternary nitrogen to the basic skeleton of the cellulose, respectively, the conformation of the alkyl substituent that forms the chain of the extractant and distances the hanging group. The length of the alkyl substituent, although differing only by two carbon atoms, in the order of dodecyl, tetradecyl, hexadecyl, tends to adopt different conformations [38], and implicitly the distance determined by the alkyl chain from the cellulose skeleton increases in the order of TDTMABr, DDTMABr, HDTMACl. Therefore, the strongest antibacterial effect has the TDTMABr extractant, regardless of the studied functionalization ratio. This statement is in line with the data in the literature, which claims that the structure of the cell wall is destroyed and cell viability is disrupted by the action of hydrophobic compounds [53-57].

Regarding the effect on P. aeruginosa, all tested ammonium salt extractants showed a bactericidal effect, correlated with the amount of extractant used for functionalization. The maximum inhibition rate was not reached at any of the studied ratios, and a much higher amount of biocide is likely to be required. The outer membrane of the bacterial cell in $P$. aeruginosa is an important selective barrier, which results in reduced adsorption of the biocide in the cell due to the reduced susceptibility of this species to biocidal agents [58].

Previous research results on quaternary ammonium cellulose salts have shown that they can be used successfully in wastewater treatment as flocculants $[21,59,60]$. According to this study, its use is also recommended in terms of the effectiveness of its antibacterial effect on wastewater.

B. Materials obtained by functionalization of cellulose with extractants containing phosphonium salts

B.1. Studies to determine the optimal cellulose:extractant ratio

Regardless of the phosphonium salt used for functionalization, the obtained material's antimicrobial activity is directly dependent on the increase of the functionalization ratio (Figure 5).

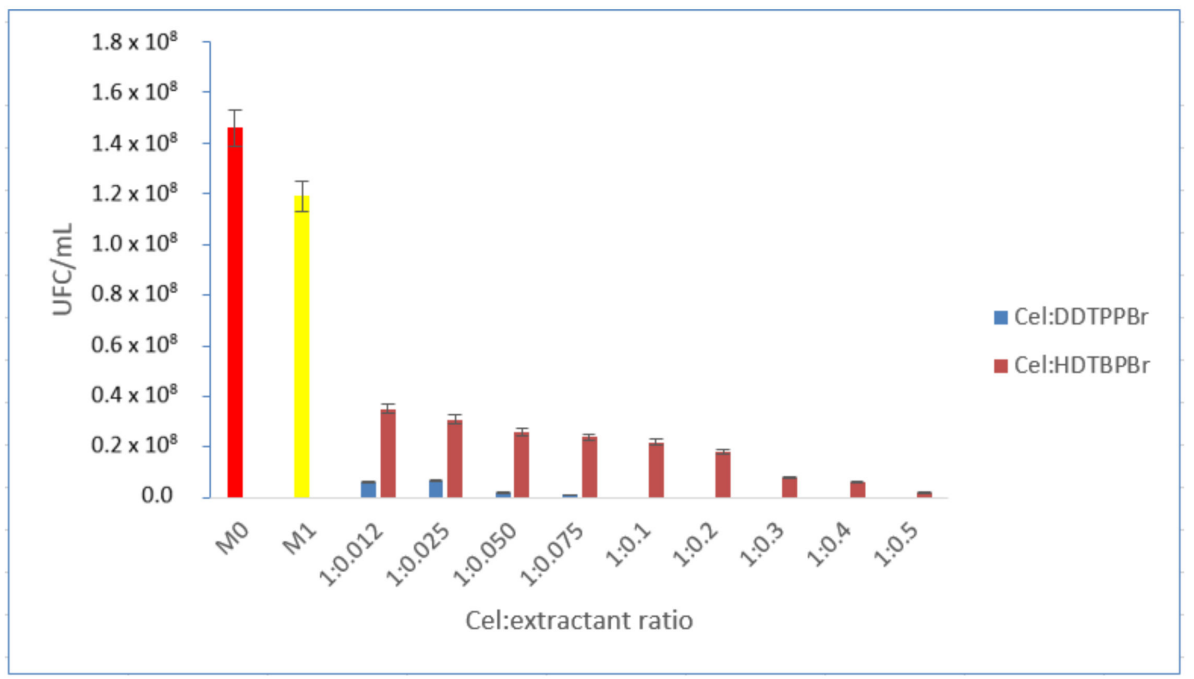

Figure 5. Comparison of the control sample (M0)—cellulose (M1)—cellulose:extractant (quaternary phosphonium salts).

When phosphonium salts were used as extractants, DDTPPBr showed a total antimicrobial effect at the functionalization ratio Cel:DDTPPBr $=1: 0.1$, while HDTBPBr showed a very good antimicrobial effect starting with the functional ratio Cel:HDTBPBr $=1: 0.3$, but 
did not show total bactericidal effect even at the ratio Cel:HDTBPBr $=1: 0.5$. Consequently, the optimal functionalization ratio for DDTPPBr is considered Cel:DDTPPBr $=1: 0.1$, and for $\mathrm{HDTBPBr}$ the optimal ratio is Cel:HDTBPBr $=1: 0.5$.

\section{B.2. Antimicrobial effect of phosphonium materials on reference microbial strains}

In the case of phosphonium salt extractants, they differ both in the length of the chain of the alkyl substituent grafted on the basic structure of the cellulose (dodecyl and hexadecyl) and in the different quaternization substituent (triphenyl and tributyl, respectively). The calculated microbial inhibition rates for each material studied are shown in Table 3.

Table 3. Inhibition rate of microbial growth when using phosphonium materials.

\begin{tabular}{|c|c|c|c|c|c|}
\hline \multirow[b]{2}{*}{ Material } & \multirow{2}{*}{$\begin{array}{c}\text { Cel:Extractant } \\
\text { Ratio }\end{array}$} & \multicolumn{4}{|c|}{ Inhibition Rate (\%) } \\
\hline & & $\begin{array}{c}\text { Staphylococcus aureus } \\
\text { ATCC } 25923\end{array}$ & $\begin{array}{c}\text { Pseudomonas } \\
\text { aeruginosa ATCC } 27853\end{array}$ & $\begin{array}{c}\text { Escherichia coli } \\
\text { ATCC } 25922\end{array}$ & $\begin{array}{c}\text { Candida albicans } \\
\text { ATCC } 10231\end{array}$ \\
\hline \multirow{2}{*}{ Cel:DDTPPBr } & 1:0.012 & 100.0 & 32.0 & 100.0 & 100.0 \\
\hline & 1:0.1 & 100.0 & 39.8 & 100.0 & 100.0 \\
\hline \multirow{5}{*}{ Cel:HDTPPBr } & 1:0.012 & 30.7 & 8.4 & 42.7 & 65.3 \\
\hline & 1:0.05 & 58.7 & 20.7 & 44.9 & 67.0 \\
\hline & 1:0.1 & 69.7 & 21.6 & 52.6 & 77.9 \\
\hline & 1:0.3 & 100.0 & 26.6 & 87.3 & 100.0 \\
\hline & 1:0.5 & 100.0 & 42.6 & 89.1 & 100.0 \\
\hline
\end{tabular}

In the case of DDTPPBr, the antibacterial and antifungal effect was manifested with an inhibition rate of $100 \%$, regardless of the functionalization ratio, except for the plates inoculated with P. aeruginosa. In the case of P. aeruginosa, the 10-fold increase in functional ratio did not lead to a substantial increase in the rate of bacterial inhibition, which increased only from $32 \%$ to $39.8 \%$. This aspect can be explained by the resistance of $P$. aeruginosa species [58] to numerous agents with bactericidal effects and the need to use a quantity of extractant for functionalization that is not economically justified.

When using materials with HDTBPBr, the total bactericidal effect was obtained for $S$. aureus strain at the functionalization ratio Cel:HDTBPBr $=1: 0.3$. The total antifungal effect was obtained in the case of this material, also at the functionalization ratio Cel:HDTBPBr $=1: 0.3$. This could be explained by the resemblance of the cell walls of Gram-positive bacteria to the fungal wall, at least in terms of the wall structure of $C$. albicans species [51,52]. It was also found that the rate of inhibition of bacterial and fungal growth, respectively, is directly proportional to the functionalization ratio. In both Gram-negative bacteria tested, $\mathrm{HDTBPBr}$ failed to reach the maximum inhibition rate. On P. aeruginosa, even if the Cel:HDTBPBr functionalization ratio was increased 10-fold, from 0.01 to 0.1 , the inhibition rate increased from $6 \%$ to $21.6 \%$. Respectively, as the functional ratio increased from 0.1 to 0.5 , the inhibition rate increased from $21.6 \%$ to $42.6 \%$. The same effect was observed on the E. coli strain when the increase of the functionalization ratio by 50 times (from 0.01 to 0.5 ) determined only a doubling of the increase of the inhibition rate, from $42.7 \%$ to $89.1 \%$.

DDTPPBr is the extractant whose hydrophobicity is much higher than that of HDTBPBr because even if the alkyl substituent is shorter in the case of DDTPPBr (dodecyl versus hexadecyl), the phenyl substituent with which this extractant is quaternized has a high degree of hydrophobicity compared to the butyl substituent from HDTBPBr. On the other hand, being shorter, the alkyl segment causes a smaller distance of the pendant group from the basic structure of cellulose, which again increases the antimicrobial effect. All these findings are supported by data from the literature that emphasize the role of the hydrophilic-hydrophobic balance of the bacterial cell wall and the hydrophobicity of the antibacterial agent in the manifestation of the bactericidal effect [53,55,56,61]. Moreover, the electrostatic attraction between the functionalized cellulose and the bacterial cell membrane 
plays an essential role in the bactericidal effect, as the strong electrostatic attraction forces in the adsorbed polyelectrolyte and the lipid molecules in the bacterial cell membrane ultimately destroy the bacterial cell $[61,62]$.

C. Materials obtained by functionalizing cellulose with sulfur compounds

C.1. Studies to determine the optimal cellulose:extractant ratio

Compared to the analysis of the M1 control sample, when non-functionalized cellulose allowed the growth of bacteria on the surface of the culture medium, it can be concluded that by functionalizing cellulose with MBT and THIO, increasing functionalization ratio, bactericidal capacity is positively influenced (Figure 6).

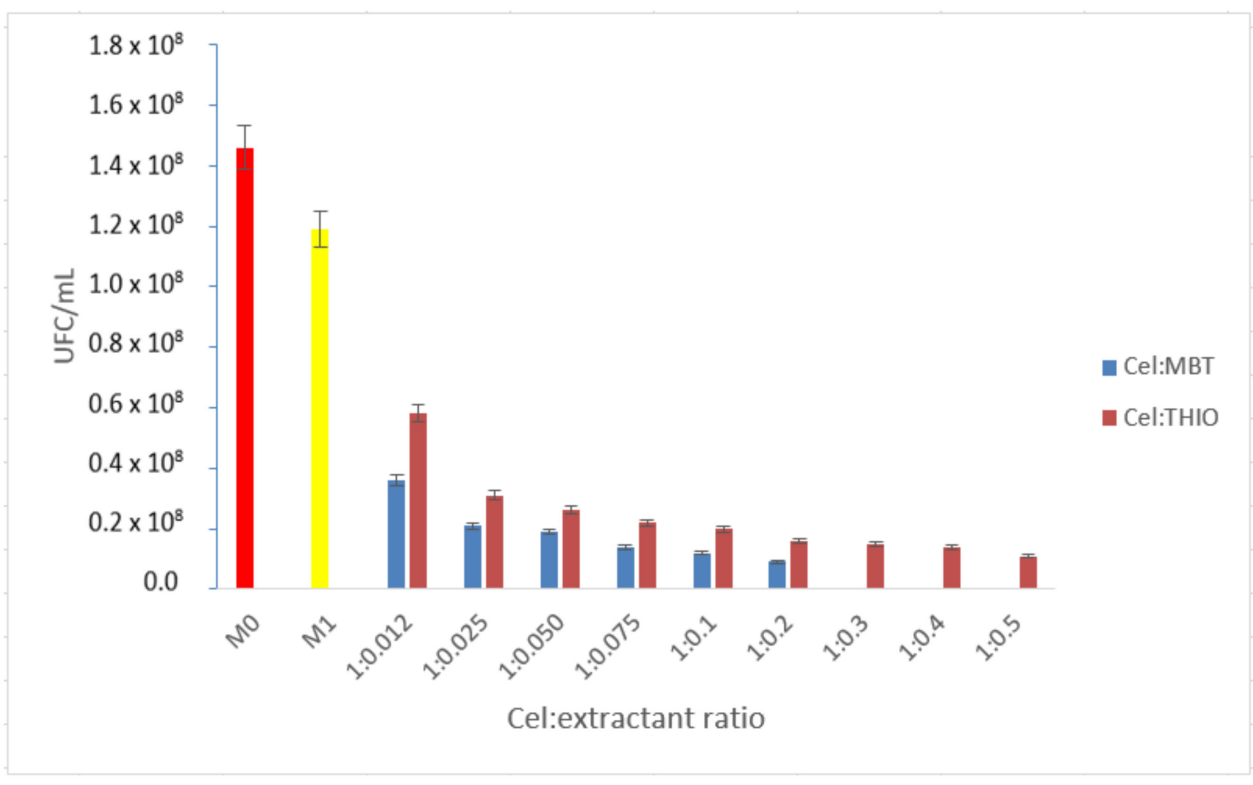

Figure 6. Comparison of the control sample (M0)—cellulose (M1)—cellulose:extractant (compounds containing sulfur).

After examining the series of microbial cultures in which MBT was used as an extractant, it was found that there was no microbial growth at the ratio Cel:MBT =1:0.3; there was no microbial growth. Thus, the ratio that showed total bactericidal effect and is considered as optimal working ratio is 1:0.3.

For the THIO extractant, regardless of the studied functionalization ratio, no total bactericidal effect was obtained, proven by the maximum calculated bactericidal inhibition rate of $90.8 \%$ for the functionalization ratio of $1: 0.5$. In order to establish the optimal working ratio, given that we cannot talk about the total bactericidal effect, we considered the optimal ratio $\mathrm{Cel}: \mathrm{THIO}=1: 0.5$.

\section{C.2. Antimicrobial effect of sulfur materials on reference microbial strains}

The efficiency of the materials obtained by functionalizing cellulose with sulfurcontaining extractants is expressed, in the form of the rate of microbial inhibition, in Table 4.

The functionalization of cellulose with MBT or THIO has led to the improved antibacterial and antifungal activity of native cellulose, proven by obtaining a higher inhibition rate for Cel-MBT and Cel-THIO materials than native cellulose, even for the minimum functionalization ratio Cel:extractant $=1: 0.012$.

We compared the efficiency of the functionalized material with MBT on the tested species. We find that the antimicrobial effect is better in the case of Gram-positive bacterial and fungal species, proven by the $100 \%$ inhibition rate achieved for a functionalization ratio Cel:MBT = 1:0.1 for both $S$. aureus and $C$. albicans. The similar manifestation of the antimicrobial effect exerted by the two species under the action of the MBT-based 
materials tested is suggestive, as the inhibition rate calculated for the functional ratio 1:0.05 is approximately equal ( $62.9 \%$ for S. aureus and $63.2 \%$ for C. albicans). When the effect of these sulfur-containing materials on Gram-negative bacteria was studied, their efficacy was found to be directly related to the increase in the amount of extractant and to the increase in functionalization ratio, but the maximum bacterial inhibition rate was obtained only for E. coli at a ratio Cel:MBT =1:0.5. The functionalization of cellulose with THIO, even at the highest functionalization ratio, had no total antimicrobial effect. We could rather speak of the bacteriostatic or fungistatic effect in the case of materials functionalized with thiourea. Suppose we consider sufficient the manifestation of the bacteriostatic or fungistatic effect. In that case, it is found that the newly synthesized biomaterial prevented the growth of bacteria without necessarily killing them, observing an inactivation of microbial strain growth, as shown by the analysis of inhibition rates presented in Table 4.

Table 4. Microbial growth inhibition rate when using sulfur materials.

\begin{tabular}{|c|c|c|c|c|c|}
\hline \multirow[b]{2}{*}{ Material } & \multirow{2}{*}{$\begin{array}{l}\text { Cel:Extractant } \\
\text { Ratio }\end{array}$} & \multicolumn{4}{|c|}{ Inhibition Rate (\%) } \\
\hline & & $\begin{array}{c}\text { Staphylococcus aureus } \\
\text { ATCC } 25923\end{array}$ & $\begin{array}{c}\text { Pseudomonas } \\
\text { aeruginosa ATCC } 27853\end{array}$ & $\begin{array}{l}\text { Escherichia coli } \\
\text { ATCC } 25922\end{array}$ & $\begin{array}{c}\text { Candida albicans } \\
\text { ATCC } 10231\end{array}$ \\
\hline \multirow{5}{*}{ Cel:MBT } & 1:0.012 & 25.6 & 10.0 & 20.5 & 54.0 \\
\hline & 1:0.05 & 62.9 & 13.7 & 22.1 & 63.2 \\
\hline & 1:0.1 & 100.0 & 19.5 & 50.4 & 100.0 \\
\hline & 1:0.3 & 100.0 & 36.2 & 65.4 & 100.0 \\
\hline & 1:0.5 & 100.0 & 41.0 & 100.0 & 100.0 \\
\hline \multirow{5}{*}{ Cel:THIO } & 1:0.012 & 20.7 & 12.9 & 28.9 & 52.5 \\
\hline & 1:0.05 & 27.7 & 20.7 & 49.6 & 55.8 \\
\hline & 1:0.1 & 39.3 & 39.6 & 51.0 & 54.5 \\
\hline & 1:0.3 & 75.3 & 44.5 & 52.4 & 60.1 \\
\hline & 1:0.5 & 76.0 & 45.1 & 55.5 & 60.9 \\
\hline
\end{tabular}

In Table 5, we synthesized a comparison between the antimicrobial effect (regarding the inhibition of microbial growth) of the materials synthesized in the present paper and other studies.

Table 5. Comparison between cellulose derivative and antimicrobial effect.

\begin{tabular}{|c|c|c|}
\hline Material & $\begin{array}{l}\text { Antimicrobial Effect (Inhibition } \\
\text { Rate \%) upon Microbial Strain }\end{array}$ & References \\
\hline $\begin{array}{l}\text { Cellulose with } \\
\text { octadecyldimethyl(3-trimethoxysilylpropyl) } \\
\text { ammonium chloride }\end{array}$ & $\begin{array}{l}96-99 \% \text { on } E . \text { coli } \\
>99 \% \text { on S. aureus }\end{array}$ & {$[63]$} \\
\hline Silver-cellulose fiber sheets & $\begin{array}{c}91.58-99.46 \% \text { on } S . \text { aureus } \\
93.6-99.78 \% \text { on E. coli } \\
97.5-100 \% \text { on C. albicans }\end{array}$ & [43] \\
\hline Propane sulfonated chitosan & $\begin{array}{l}78.8 \% \text { on Phomopsis asparagi } \\
80.2 \% \text { on Fusarium oxysporum }\end{array}$ & {$[44]$} \\
\hline Dipropane sulfonated chitosan & $\begin{array}{l}82.2 \% \text { on Phomopsis asparagi } \\
94 \% \text { on Fusarium oxysporum }\end{array}$ & [44] \\
\hline Gold nanoparticles & $\begin{array}{c}5.4-20.0 \% \text { on } \text { E. coli } \\
4.6-16.3 \% \text { on S. aureus }\end{array}$ & [45] \\
\hline Gold nanocapsules & $\begin{array}{c}23.7-40.0 \% \text { on } E . \text { coli } \\
18.6-34.9 \% \text { on } S . \text { aureus }\end{array}$ & {$[45]$} \\
\hline
\end{tabular}


Table 5. Cont.

\begin{tabular}{|c|c|c|}
\hline Material & $\begin{array}{l}\text { Antimicrobial Effect (Inhibition } \\
\text { Rate \%) upon Microbial Strain }\end{array}$ & References \\
\hline $\begin{array}{l}\text { Chitosan derivatives based upon quaternary } \\
\text { ammonium salt }\end{array}$ & $\begin{array}{c}100 \% \text { on S. aureus * } \\
13.1-60.3 \% \text { on P. aeruginosa } \\
25.8-100.0 \% \text { on E. coli } \\
\text { * } \\
76.0-100.0 \% \text { on C. parapsilosis * }\end{array}$ & [38] \\
\hline Chitosan derivatives based upon phosphonium salt & $\begin{array}{c}100 \% \text { on } \text { S. aureus }{ }^{*} \\
28.2-48.6 \% \text { on P. aeruginosa * } \\
20.2-100.0 \text { on E. coli } \\
100.0 \% \text { on C. parapsilosis }\end{array}$ & [38] \\
\hline Chitosan derivatives based upon sulfur compound & $\begin{array}{c}38.6-100 \% \text { on S. aureus }{ }^{*} \\
22.8-46.7 \% \text { on P. aeruginosa } \\
25.8-72.3 \% \text { on E. coli } \\
\text { * } \\
80.6-100.0 \% \text { on C. parapsilosis }\end{array}$ & [38] \\
\hline $\begin{array}{l}\text { Cellulose derivatives based upon quaternary } \\
\text { ammonium salt }\end{array}$ & $\begin{array}{c}100.0 \% \text { on } S . \text { aureus } \\
\text { * } \\
17.0-54.8 \% \text { on } P \text {. aeruginosa } \\
\text { 53.4-100.0\% on E. coli } \\
\text { * } \\
100 \% \text { on C. albicans }\end{array}$ & present study \\
\hline Cellulose derivatives based upon phosphonium salt & $\begin{array}{c}\text { 30.7-100.0\% on S. aureus * } \\
\text { 8.4-42.6\% on P. aeruginosa } \\
\text { 42.7-100.0\% on E. coli } \\
\text { * } \\
65.3-100.0 \% \text { on C. albicans * }\end{array}$ & present study \\
\hline Cellulose derivatives based upon sulfur compound & $\begin{array}{c}20.7-100.0 \% \text { on S. aureus * } \\
10.0-45.1 \% \text { on P. aeruginosa } \\
20.5-100.0 \% \text { on E. coli } \\
52.5-100.0 \% \text { on C. albicans }\end{array}$ & present study \\
\hline
\end{tabular}

* inhibition rate value is depending on the functionalization ratio and the tested material.

\section{Conclusions}

In the context of the resistance of microbial strains to most bactericidal agents known to date, the development of new antibacterial materials or at least with bacteriostatic properties, starting from biomaterials, has opened new opportunities to inhibit microbial adhesion and limit their transmission. As the polyolic nature of cellulose allows it to bind a series of compounds with chemical functions that can modulate the hydrophilic/lipophilic balance so that it can provide improved properties, we are determined to consider this biopolymer as a good support material applicable in many fields. For example, with regard to the use of cellulose derivatives in food preservation technology, the identification of new biomaterials with antibacterial properties is one of the most promising trends. It is even desirable to obtain such antibacterial materials that are biodegradable, which is why the study of cellulose is desirable. Moreover, the antimicrobial potential of cellulose functionalized in wastewater treatment should not be neglected, especially in terms of water disinfection, as evidenced by the results obtained in this study.

The impregnation technique used in this paper for the functionalization of cellulose is an easy way to obtain cellulose derivatives without involving the production of reaction by-products. On the other hand, in the case of all cellulose derivatives obtained by impregnation, increased antimicrobial properties were obtained compared to native cellulose, which leads to the conclusion that this impregnation technique can be used successfully to obtain new materials with very good antimicrobial effect.

Growth inhibition of S. aureus, E. coli, and C. albicans strains was determined by using materials with DDTMABr, TDTMABr, and DDTPPBr, regardless of the functionalization ratio. Materials obtained by functionalizing cellulose with quaternary ammonium and phosphonium salts showed substantial antibacterial capacity against S. aureus, E. coli, C. albicans (up to $100 \%$ ), and P. aeruginosa (maximum 54.8\%) even at very low concentra- 
tions of surface-immobilized antimicrobial agent. In the case of materials obtained by functionalization with quaternary ammonium salts, the antibacterial activity was dependent on the alkyl chain's length, which distances the quaternary salt's pendant group from the basic structure of the cellulose. In this sense, the antimicrobial effect was proved in the order of TDTMABr $>$ DDTMABr $>\mathrm{HDTMACl}$, respecting at the same time the increase of the ratio between the support material and extractant.

In the case of materials obtained by the functionalization of cellulose with phosphonium quaternary salts, the antibacterial activity was strongly influenced by the hydrophobic character of the pendant group (phenyl compared to butyl), in addition to the distance given by the alkyl substituent of the quaternary salt (dodecyl compared to hexadecyl) was added. The best antimicrobial effect was observed when it was used DDTPPBr like extractant, even at lower support:extractant ratio $=1: 0.012$.

Materials obtained by functionalizing cellulose with sulfur extractants have generally shown a bacteriostatic or fungistatic effect, with a maximum of $76 \%$ inhibition rate upon S. aureus at the highest functionalized support:extractant ratio $=1: 0.5$. The exception was in the case of Cel-MBT when the maximum inhibition rate on S. aureus and C. albicans was reached at the functionalization ratio Cel:MBT $=1: 0.3$.

The abundance of polysaccharides can effectively prepare antibacterial materials either by enhancing or modulating natural antibacterial properties (such as chitosan) or by de novo imparting these properties to cellulose or other biopolymers makes these biomaterials increasingly often studied, and their applicability increasingly varied. The combination of antibacterial activity with other well-known properties of these polysaccharides opens up good perspectives for the future development of such innovative functional materials.

Author Contributions: N.S.N., C.A., M.C., C.P., D.D.-S. and D.M. carried out experiments, P.N. and C.M.D. analyzed the results, N.D., A.N. and N.S.N. wrote the paper. All authors have read and agreed to the published version of the manuscript.

Funding: Not applicable.

Institutional Review Board Statement: Not applicable.

Informed Consent Statement: Not applicable.

Data Availability Statement: Not applicable.

Conflicts of Interest: The authors declare no conflict of interest.

\section{References}

1. Shanks, R.A. 2-Chemistry and structure of cellulosic fibres as reinforcements in natural fibre composites. In Natural Fibre Composites; Hodzic, A., Shanks, R., Eds.; Woodhead Publishing: Sawston, UK, 2014; pp. 66-83.

2. Malmström, E.; Carlmark, A. Controlled grafting of cellulose fibres-An outlook beyond paper and cardboard. Polym. Chem. 2012, 3, 1702-1713. [CrossRef]

3. Moriana, R.; Vilaplana, F.; Ek, M. Cellulose Nanocrystals from Forest Residues as Reinforcing Agents for Composites: A Study from Macro- to Nano-Dimensions. Carbohydr. Polym. 2016, 139, 139-149. [CrossRef] [PubMed]

4. Malucelli, L.C.; Lacerda, L.G.; Dziedzic, M.; da Silva Carvalho Filho, M.A. Preparation, properties and futureperspectives of nanocrystals from agro-industrial residues: A review of recentresearch. Rev. Environ. Sci. Bio/Technol. 2017, 16, 131-145. [CrossRef]

5. Khattak, S.; Wahid, F.; Liu, L.-P.; Jia, S.-R.; Chu, L.-Q.; Xie, Y.-Y.; Li, Z.-X.; Zhong, C. Applications of cellulose and chitin/chitosan derivatives and composites as antibacterial materials: Current state and perspectives. Appl. Microbiol. Biotechnol. 2019, 103, 1989-2006. [CrossRef] [PubMed]

6. Kupnik, K.; Primožič, M.; Kokol, V.; Leitgeb, M. Nanocellulose in Drug Delivery and Antimicrobially Active Materials. Polymers 2020, 12, 2825. [CrossRef] [PubMed]

7. Lavoine, N.; Desloges, I.; Dufresne, A.; Bras, J. Microfibrillated cellulose-Its barrier properties and applications in cellulosic materials: A review. Carbohydr. Polym. 2012, 90, 735-764. [CrossRef] [PubMed]

8. Wu, J.; Zheng, Y.; Song, W.; Luan, J.; Wen, X.; Wu, Z.; Chen, X.; Wang, Q.; Guo, S. In situ synthesis of silver-nanoparticles/bacterial cellulose composites for slow-released antimicrobial wound dressing. Carbohydr. Polym. 2014, 102, 762-771. [CrossRef]

9. Jonoobi, M.; Oladi, R.; Davoudpour, Y.; Oksman, K.; Dufresne, A.; Hamzeh, Y.; Davoodi, R. Different preparation methods and properties of nanostructured cellulose from various natural resources and residues: A review. Cellulose 2015, 22, 935-969. [CrossRef] 
10. Kafle, K.; Shin, H.; Lee, C.M.; Park, S.; Kim, S.H. Progressive structural changes of Avicel, bleached softwood and bacterial cellulose during enzymatic hydrolysis. Sci. Rep. 2015, 5, 15102. [CrossRef]

11. Pal, S.; Nisi, R.; Stoppa, M.; Licciulli, A. Silver-Functionalized Bacterial Cellulose as Antibacterial Membrane for Wound-Healing Applications. ACS Omega 2017, 2, 3632-3639. [CrossRef]

12. Zheng, L.; Li, S.; Luo, J.; Wang, X. Latest Advances on Bacterial Cellulose-Based Antibacterial Materials as Wound Dressings. Front. Bioeng. Biotechnol. 2020, 8, 1334. [CrossRef] [PubMed]

13. Bano, S.; Negi, Y.S. Studies on cellulose nanocrystals isolated from groundnut shells. Carbohydr. Polym. 2017, 157, 1041-1049. [CrossRef] [PubMed]

14. Habibi, Y.; Lucia, L.A.; Rojas, O.J. Cellulose Nanocrystals: Chemistry, Self-Assembly, and Applications. Chem. Rev. 2010, 110, 3479-3500. [CrossRef] [PubMed]

15. George, J.; Sabapathi, S.N. Cellulose nanocrystals: Synthesis, functional properties, and applications. Nanotechnol. Sci. Appl. 2015, 8, 45. [CrossRef]

16. Wang, S.; Lu, A.; Zhang, L. Recent advances in regenerated cellulose materials. Prog. Polym. Sci. 2016, 53, 169-206. [CrossRef]

17. Siqueira, G.; Bras, J.; Dufresne, A. Cellulosic Bionanocomposites: A Review of Preparation, Properties and Applications. Polymers 2010, 2, 728. [CrossRef]

18. Bruel, C.; Tavares, J.R.; Carreau, P.J.; Heuzey, M.-C. The structural amphiphilicity of cellulose nanocrystals characterized from their cohesion parameters. Carbohydr. Polym. 2019, 205, 184-191. [CrossRef]

19. Sperandeo, P.; Bosco, F.; Clerici, F.; Polissi, A.; Gelmi, M.L.; Romanelli, A. Covalent Grafting of Antimicrobial Peptides onto Microcrystalline Cellulose. ACS Appl. Bio Mater. 2020, 3, 4895-4901. [CrossRef]

20. Baghaei, B.; Skrifvars, M. All-Cellulose Composites: A Review of Recent Studies on Structure, Properties and Applications. Molecules 2020, 25, 2836. [CrossRef]

21. Coma, V.; Freire, V.; Silvestre, A. Recent Advances on the Development of Antibacterial Polysaccharide-Based Materials; Springer: Cham, Switzerland, 2015; pp. 1751-1803. [CrossRef]

22. Kar, M.; Chourasiya, Y.; Maheshwari, R.; Tekade, R.K. Chapter 2-Current Developments in Excipient Science: Implication of Quantitative Selection of Each Excipient in Product Development. In Basic Fundamentals of Drug Delivery; Tekade, R.K., Ed.; Academic Press: Cambridge, MA, USA, 2019; pp. 29-83.

23. Klemm, D.; Heublein, B.; Fink, H.-P.; Bohn, A. Cellulose: Fascinating Biopolymer and Sustainable Raw Material. Angew. Chem. Int. Ed. 2005, 44, 3358-3393. [CrossRef]

24. Li, Q.; Wang, Y.; Wu, Y.; He, K.; Li, Y.; Luo, X.; Li, B.; Wang, C.; Liu, S. Flexible cellulose nanofibrils as novel pickering stabilizers: The emulsifying property and packing behavior. Food Hydrocoll. 2019, 88, 180-189. [CrossRef]

25. Huang, S.; Liu, X.; Chang, C.; Wang, Y. Recent developments and prospective food-related applications of cellulose nanocrystals: A review. Cellulose 2020, 27, 2991-3011. [CrossRef]

26. Tamilselvi, A.; Jayakumar, G.C.; Sri Charan, K.; Sahu, B.; Deepa, P.R.; Kanth, S.V.; Kanagaraj, J. Extraction of cellulose from renewable resources and its application in leather finishing. J. Clean. Prod. 2019, 230, 694-699. [CrossRef]

27. Salmeia, K.; Jovic, M.; Ragaišienè, A.; Rukuižienè, Ž.; Milašius, R.; Mikučionienè, D.; Gaan, S. Flammability of Cellulose-Based Fibers and the Effect of Structure of Phosphorus Compounds on Their Flame Retardancy. Polymers 2016, 8, 293. [CrossRef]

28. Ullah, H.; Wahid, F.; Santos, H.A.; Khan, T. Advances in biomedical and pharmaceutical applications of functional bacterial cellulose-based nanocomposites. Carbohydr. Polym. 2016, 150, 330-352. [CrossRef]

29. Ayala Valencia, G.; Cristina de Oliveira Vercik, L.; Ferrari, R.; Vercik, A. Synthesis and characterization of silver nanoparticles using water-soluble starch and its antibacterial activity on Staphylococcus aureus. Starch—Stärke 2013, 65, 931-937. [CrossRef]

30. Kalwar, K.; Bhutto, M.A.; Li, D.L.; Shan, D. Cellulose based nanofabrication; immobilization of silver nanoparticales and its size effect against Escherichia coli. Mater. Res. Express 2017, 4, 6. [CrossRef]

31. Wang, J.; Liu, W.; Li, H.; Huili, W.; Wang, Z.; Zhou, W.; Liu, H. Preparation of cellulose fiber-TiO ${ }_{2}$ nanobelt-silver nanoparticle hierarchically structured hybrid paper and its photocatalytic and antibacterial properties. Chem. Eng. J. 2013, 228, $272-280$. [CrossRef]

32. Bolhuis, G.K.; Armstrong, N.A. Excipients for direct compaction-An update. Pharm. Dev. Technol. 2006, 11, 111-124. [CrossRef]

33. Liu, S.; Zeng, J.; Tao, D.; Na, N. Microfiltration performance of regenerated cellulose membrane prepared at low temperature for wastewater treatment. Cellulose 2010, 17, 1159-1169. [CrossRef]

34. Fauzani, D.; Notodarmojo, S.; Handajani, M.; Helmy, Q.; Kardiansyah, T. Cellulose in natural flocculant applications: A review. J. Phys. Conf. Ser. 2021, 2047, 012030. [CrossRef]

35. Suopajärvi, T.; Liimatainen, H.; Hormi, O.; Niinimäki, J. Coagulation-flocculation treatment of municipal wastewater based on anionized nanocelluloses. Chem. Eng. J. 2013, 231, 59-67. [CrossRef]

36. Khiari, R.; Dridi-Dhaouadi, S.; Aguir, C.; Mhenni, M.F. Experimental evaluation of eco-friendly flocculants prepared from date palm rachis. J. Environ. Sci. 2010, 22, 1539-1543. [CrossRef]

37. Onwukamike, K.N.; Grelier, S.; Grau, E.; Cramail, H.; Meier, M.A.R. Critical Review on Sustainable Homogeneous Cellulose Modification: Why Renewability Is Not Enough. ACS Sustain. Chem. Eng. 2019, 7, 1826-1840. [CrossRef]

38. Ardean, C.; Davidescu, C.M.; Nemeş, N.S.; Negrea, A.; Ciopec, M.; Duteanu, N.; Negrea, P.; Duda-Seiman, D.; Muntean, D. Antimicrobial Activities of Chitosan Derivatives. Pharmaceutics 2021, 13, 1639. [CrossRef] 
39. Cortina, J.L.; Miralles, N.; Sastre, A.; Aguilar, M.; Profumo, A.; Pesavento, M. Solvent-impregnated resins containing di-(2,4,4trimethylpentyl) phosphonic acid I. Comparative study of di-(2,4,4-trimethylpentyl)phosphinic acid adsorbed into Amberlite XAD-2 and dissolved in toluene. React. Polym. 1993, 21, 89-101. [CrossRef]

40. Cortina, J.L.; Miralles, N.; Sastre, A.M.; Aguilar, M.; Profumo, A.; Pesavento, M. Solvent-impregnated resins containing di-(2,4,4trimethylpentyl) phosphinic acid II. Study of the distribution equilibria of Zn(II), Cu(II) and Cd(II). React. Polym. 1993, 21, 103-116. [CrossRef]

41. Cortina, J.L.; Miralles, N.; Aguilar, M.; Sastre, M. Solvent impregnated resins containing di(2-ethylhexyl)phosphoric acid. I. Preparation and study of the retention and distribution of the extractant on the resin. Solvent Extr. Ion Exch. 1994, 12, 349-369. [CrossRef]

42. Warshawsky, A. Extraction with Solvent-Impregnated Resins. In Ion Exchange and Solvent Extraction; Marinsky, J.A., Marcus, Y., Eds.; Marcel Dekker: New York, NY, USA, 1981; Volume 8, pp. 229-310.

43. Csóka, L.; Božanić, D.K.; Božanić, D.K.; Nagy, V.; Dimitrijević-Branković, S.; Luyt, A.S.; Grozdits, G.; Djoković, V. Viscoelastic properties and antimicrobial activity of cellulose fiber sheets impregnated with Ag nanoparticles. Carbohydr. Polym. 2012, 90, 1139-1146. [CrossRef]

44. Luan, F.; Wei, L.; Zhang, J.; Mi, Y.; Dong, F.; Li, Q.; Guo, Z. Antioxidant Activity and Antifungal Activity of Chitosan Derivatives with Propane Sulfonate Groups. Polymers 2018, 10, 395. [CrossRef]

45. Belbekhouche, S.; Bousserrhine, N.; Alphonse, V.; Le Floch, F.; Mechiche, Y.C.; Menidjel, I.; Carbonnier, B. Chitosan based self-assembled nanocapsules as antibacterial agent. Colloids Surf. B Biointerfaces 2019, 181, 158-165. [CrossRef] [PubMed]

46. Syamani, F.A.; Suryani, A. Changes in Oil Palm Frond Fiber Morphology, Cellulose Crystallinity and Chemical Functional Groups during Cellulose Extraction Phases. Chem. Mater. Res. 2015, 7, 113-121.

47. Nazir, F.; Iqbal, M. Synthesis, Characterization and Cytotoxicity Studies of Aminated Microcrystalline Cellulose Derivatives against Melanoma and Breast Cancer Cell Lines. Polymers 2020, 12, 2634. [CrossRef] [PubMed]

48. Tarchoun, A.F.; Trache, D.; Klapötke, T.M.; Derradji, M.; Bessa, W. Ecofriendly isolation and characterization of microcrystalline cellulose from giant reed using various acidic media. Cellulose 2019, 26, 7635-7651. [CrossRef]

49. Negrea, A.; Gabor, A.; Davidescu, C.M.; Ciopec, M.; Negrea, P.; Duteanu, N.; Barbulescu, A. Rare Earth Elements Removal from Water Using Natural Polymers. Sci. Rep. 2018, 8, 316. [CrossRef] [PubMed]

50. Hospodarova, V.; Singovszka, E.; Stevulova, N. Characterization of Cellulosic Fibers by FTIR Spectroscopy for Their Further Implementation to Building Materials. Am. J. Anal. Chem. 2018, 09, 303-310. [CrossRef]

51. Brown, L.; Wolf, J.M.; Prados-Rosales, R.; Casadevall, A. Through the wall: Extracellular vesicles in Gram-positive bacteria, mycobacteria and fungi. Nat. Rev. Microbiol. 2015, 13, 620-630. [CrossRef]

52. Carolus, H.; Van Dyck, K.; Van Dijck, P. Candida albicans and Staphylococcus Species: A Threatening Twosome. Front. Microbiol. 2019, 10, 2162. [CrossRef]

53. Kumariya, R.; Sood, S.K.; Rajput, Y.S.; Saini, N.; Garsa, A.K. Increased membrane surface positive charge and altered membrane fluidity leads to cationic antimicrobial peptide resistance in Enterococcus faecalis. Biochim. Biophys. Acta (BBA)—Biomembr. 2015, 1848, 1367-1375. [CrossRef]

54. Russell, A.D. Similarities and differences in the responses of microorganisms to biocides. J. Antimicrob. Chemother. 2003, 52, 750-763. [CrossRef]

55. Krasowska, A.; Sigler, K. How microorganisms use hydrophobicity and what does this mean for human needs? Front. Cell. Infect. Microbiol. 2014, 4, 112. [CrossRef] [PubMed]

56. Palmer, J.; Flint, S.; Brooks, J. Bacterial cell attachment, the beginning of a biofilm. J. Ind. Microbiol. Biotechnol. 2007, 34, 577-588. [CrossRef] [PubMed]

57. Bassetti, M.; Baguneid, M.; Bouza, E.; Dryden, M.; Nathwani, D.; Wilcox, M. European perspective and update on the management of complicated skin and soft tissue infections due to methicillin-resistant Staphylococcus aureus after more than 10 years of experience with linezolid. Clin. Microbiol. Infect. Off. Publ. Eur. Soc. Clin. Microbiol. Infect. Dis. 2014, 20 (Suppl. S4), 3-18. [CrossRef] [PubMed]

58. Ciofu, O.; Tolker-Nielsen, T. Tolerance and Resistance of Pseudomonas aeruginosa Biofilms to Antimicrobial Agents-How P. aeruginosa Can Escape Antibiotics. Front. Microbiol. 2019, 10, 913. [CrossRef] [PubMed]

59. Koshani, R.; Tavakolian, M.; van de Ven, T.G.M. Cellulose-based dispersants and flocculants. J. Mater. Chem. B 2020, 8, 10502-10526. [CrossRef] [PubMed]

60. Song, Y.; Zhang, J.; Gan, W.; Zhou, J.; Zhang, L. Flocculation Properties and Antimicrobial Activities of Quaternized Celluloses Synthesized in $\mathrm{NaOH} /$ Urea Aqueous Solution. Ind. Eng. Chem. Res. 2010, 49, 1242-1246. [CrossRef]

61. Thewes, N.; Loskill, P.; Jung, P.; Peisker, H.; Bischoff, M.; Herrmann, M.; Jacobs, K. Hydrophobic interaction governs unspecific adhesion of staphylococci: A single cell force spectroscopy study. Beilstein J. Nanotechnol. 2014, 5, 1501-1512. [CrossRef]

62. Chen, C.; Petterson, T.; Illergård, J.; Ek, M.; Wågberg, L. Influence of Cellulose Charge on Bacteria Adhesion and Viability to PVAm/CNF/PVAm-Modified Cellulose Model Surfaces. Biomacromolecules 2019, 20, 2075-2083. [CrossRef]

63. Andresen, M.; Stenstad, P.; Møretrø, T.; Langsrud, S.; Syverud, K.; Johansson, L.S.; Stenius, P. Nonleaching antimicrobial films prepared from surface-modified microfibrillated cellulose. Biomacromolecules 2007, 8, 2149-2155. [CrossRef] 